\title{
Surmakultuuri suundumused Eestis: Surmaended ${ }^{1}$
}

\author{
Teesid \\ Artikli eesmärgiks on anda ülevaade levinumatest surmaennetest küla- \\ ühiskonnas ja otsida vastust küsimusele, kuidas on iühiskondlikud muu- \\ tused mõjutanud inimeste mõttemaailma ja suhtumist surmakultuuri \\ valdkonda kuuluvatesse surmaennetesse. Vastates küsimusele, kas ja \\ miks surmaended on tänapäeval taandunud, saab näidata surmakul- \\ tuuri muutumist. \\ Osa surmaendeid on taandunud, sest: 1) objektidega, kelle käitumi- \\ se, oleku või väliste tunnuste järgi surma ennustati, puudub füüsiline \\ kokkupuude; 2) on leitud ratsionaalsed seletused juhtumitele, mis va- \\ rem aktualiseerisid uskumustemaailma; 3) traditsioonilised uskumused \\ on iganenud ja kaotanud sideme laiema uskumussüsteemiga; 4) usku- \\ mused on suundunud oma elukutse kaudu surmaga kokkupuutuvate \\ inimeste ametipärimuseks; 5) surmaennetel puudub tänapäeval usun- \\ diline tagapõhi. \\ Surmaendeid usutakse, sest: 1) nende aluseks on kogemuslik maa- \\ ilmavaade - nii on juba juhtunud; 2) pärimus liigub vanemalt põlvkon- \\ nalt nooremale; 3) tänapäeva maailmas on ennustamine populaarne; \\ 4) surmaküsimus tekitab inimestes huvi - kuni ei osata surma seletada, \\ otsitakse ka endeid.
}

Märksõnad: ennustamine, ametipärimus, surm, surmaenne, surmakultuur, uskumus.

Hirmus pole mitte surm, vaid teadmine tema saabumisest (A. H. Tammsaare).

\section{Sissejuhatuseks}

Surmaprobleem on üks neid, millega seisavad silmitsi kõik inimesed. Seetõttu kerkib teema märkimisväärselt esile nii folkloori erinevates liikides kui ka rahvausundis, folkloristikas ja usuteaduses. Surmaga seotud uskumused ja kombed, mis tänapäeva uurimustes koondatakse ühise nimetaja surmakultuur alla, peegeldavad inimeste ellusuhtumist erinevatel ajastutel. Surmakultuuri võib analüüsida muutumises, jälgides, kuidas uued elunähtused teevad võimatuks varasema kombe ning tingivad uusi nähtusi. Sellesse valdkonda kuuluv surmaennete teema on olnud läbi aegade rahvausundis üks delikaatsemaid. Surma kohta on raske küsimusi esitada, sest juba see võib mõjuda vanematele inimestele surmaendena. Seetõttu nõuab kogumistöö suhtlemisoskust, 


\section{Tiia Ristolainen}

moodustades uurimisprotsessi raskeima osa. Kogumissituatsioonid võivad olla väga erinevad. Intiimseid kogemusi tavaliselt rahvaluulekogujale (või võõrale) ei räägita (kuidas sa räägid, et nüüd küll juhtub midagi, sest ma nägin seda ja seda...), või kui räägitakse, ei peeta neid tõsiseltvõetavateks surmaenneteks. Samas kinnitavad paljud informandid, et nad usuvad surmaennetesse. Ühe pärimusekandja sõnul on korduvate ennete eneses kandmine raske psühholoogiline koorem, sest enamasti puudutavad need lähedasi (TK 3, $2000<$ Hiiumaa). Tihti lihtsalt vesteldakse teistega surma teemal ja põhjendatakse selle vahendusel juhtunut. Sellisel jutustamisel on samas ka stressi maandav iseloom - see pidigi nii minema, analoogilisi juhtumeid on teisedki üle elanud. Niisuguse jutustamise puhul on ühtlasi tegemist enesekaitsega.

Käesolev artikkel annab ülevaate enamlevinud surmaennetest Eesti külaühiskonnas, hõlmates varasema ainese osas kõiki piirkondi (hilisintervjuud on seotud valitud kohtadega), ning otsib vastust küsimusele, kas antud uskumused on ka tänapäeval aktuaalsed. Analüüsitav materjal pärineb Eesti Rahvaluule Arhiivist ja autori välitöödelt Saare- ja Hiiumaal, Lääne-Virumaal ning Tartus aastatel 1990-2002. Võrdlusmaterjali lisandus hiljutiselt Eesti Rahvaluule Arhiivi korraldatud pärimuse kogumise võistluselt Eluring (kajastuvad Eesti Rahvaluule Arhiivi EFA kogus). Surmaennete uurimisel on lähtutud folklooritekstidest eesmärgiga avada noteeringute tähendus. Kahjuks ei võimalda arhiivitekst konteksti uurimist. Me ei saa tegelikult teada, kas jutustaja ise usub surmaendeid või on neid lihtsalt kelleltki kuulnud ega võta tõsiselt. Teadete interpreteerimiseks ehitan üles taustsüsteemi, tuginedes peamiselt folkloristikale, usuteadusele, etnoloogiale, psühholoogiale ja kultuuriantropoloogiale.

\section{Uurimisloost}

Vanimates, 17.-18. sajandist pärinevates teaduslike sugemetega allikates esitatakse surmaendeid deskriptiivse materjalikoguna muude talupoja elu puudutavate kirjelduste hulgas, mille heaks näiteks on Johann Forseliuse ja Johann Wolfgang Boecleri raamat Der Einfältigen Ehsten Abergläubische Gebräuche, Weisen und Gewohnheiten (1685). Autorid kirjeldasid oma kaasaega teadlikust huvist ja hingekarjase ametikohuste tõttu. 19. sajandil ilmus Ferdi- 
nand Johann Wiedemanni teos Aus dem inneren und äusseren Leben der Ehsten (1876), kus muu hulgas tuuakse välja ka eestlaste surmaendeid. 20. sajandil on antud teemaga tegelnud paljud eesti rahvausundi uurijad. Matthias Johann Eisen on käsitlenud eesti surmaendeid Eesti mütoloogias (1919), eeskätt mardusega seotut. Ka Eesti mütoloogia IV (1926) esitab teiste uskumuste seas üksikuid surmaendeid. Eraldi tähelepanu neile pööratud ei ole. Oskar Loorits vaatleb eesti surmaendeid teiste uskumuste hulgas nii Eesti rahvausundi maailmavaates (1932a) kui ka teoses Grundzüge des estnischen Volksglaubens (I-III; 1949-1957), kuid see on juhuslikku laadi, sest uurija läheneb ainesele pigem

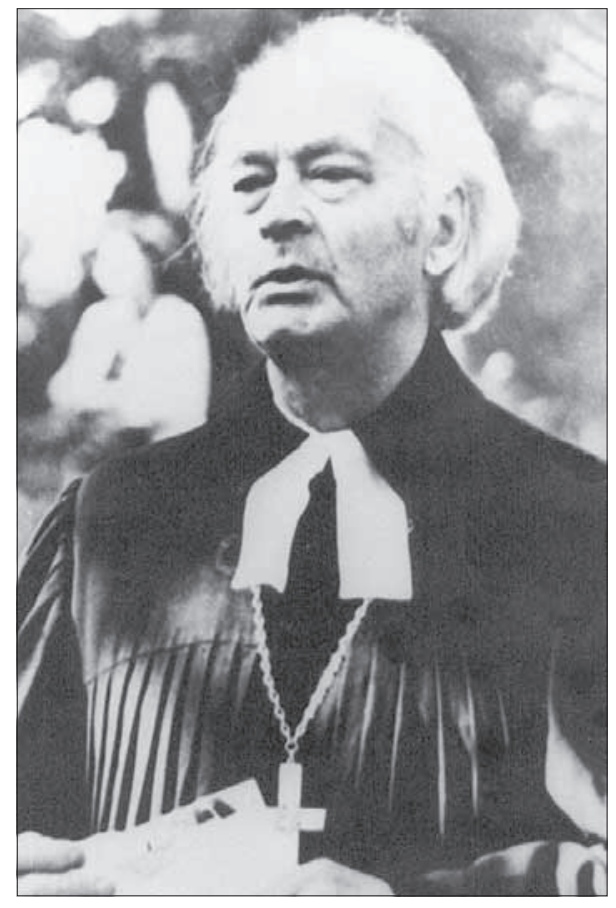

Foto 1. Viru-Jaagupi kirikuõpetaja Madis Oviir (1908-1999) on olnud folkloristidele suurepärane informant, temalt pärineb ka hulk teateid surmaennetest. Foto erakogust.

hingekontseptsioonist lähtudes. Süvenenumalt pöörab ta tähelepanu liivi surmaennetele oma uurimuses "Der Tod in der livischen Volksüberlieferung" ("Surm liivi rahvapärimuses", 1932b), kus neid on lisaks peatükile "Vorzeichen des Todes" ("Surmaended") esitatud ka teistes osades, ent eraldi käsitlemata.

20. sajandi esimene pool oli folkloristikas ja usundi uurimises veel üldteemade aeg, detailsemad käsitlused said tulla alles üldistavate kirjelduste järel - pärast Teist maailmasõda. Ka usundiuurimise teoreetik Ivar Paulson on surmaendeid käsitlenud muust usundimaterjalist eristamata Vana eesti rahvausu (1966) essees "Too ilm". Teoloog Uku Masingu Eesti usundis (ilmunud 1995. aastal enne 1940. aastat koostatud käsikirja alusel) on surmaendeid mainitud, kuid eraldi käsitlust ei ole need leidnud. 


\section{Tiia Ristolainen}

Nõukogude Eestis varjutas nimetatud teema rahvaluuleteaduse kirjanduskesksus. Käsitlemist ei soosinud kaugeltki ka ühiskonnas valitsev surma eitav ideoloogia.

20. sajandi teisel poolel on eesti surmaendeid uurinud Eha Allik (diplomitöö Eesti surmaennustused 1972) ning käesoleva artikli autor (diplomitöö Surmaended Virumaal (Köss 1990) ja magistritöö Surmaga seotud uskumused eesti rahvausundis (Köss 1998)). Eesti folkloristidest ja etnoloogidest on surmakultuuri üksikküsimused või valdkonnad olnud näiteks Ülo Tedre, Marju Torp-Kõivupuu, Argo Moori, Veera Pino, kuid ka Vaike Sarve, Mall Hiiemäe, Mare Kõiva, Eha Viluoja ja Kristi Salve oluliseks uurimisteemaks . Konkreetselt surmaendeid on lähemalt vaadelnud nt Marika Mikkor.

Surmatemaatika on lahutamatult seotud ennustamise kui tegevuse ja ennete kui nähtusega, mida on defineeritud järgnevalt:

Enne - tulevikusündmuse märgiks peetav seik või nähtus. Eesti materjali põhjal on tähtsal kohal olnud ilmaended ning inimese enda lähitulevikku või elusaatust (ka surma) märgitsevad ended, mis on valdavalt uskumuslikku laadi.

Ennustamine - tuleviku ettekuulutamine, mis baseerub mitmesugustel maagilistel viisidel (näit. arbumine) ja vahenditel (näit. sõel, laastud jne.) (ERKL 1995: 25-26).

Rahvapärast ennustamist on omakorda võimalik jagada aktiivseks ja passiivseks. Esimene on ennete teadlik ja sihipärane esilekutsumine, nt küsimine looduselt või arbumine. Teise alla jääb märkide, unenägude jm tähelepanemine ja nende alusel käitumine.

On loomulik, et passiivse ennustamise puhul eeldatakse ühiskonna heakskiitu - alles siis saab see ühistraditsiooniks (VinhaMustonen 1981: 4).

Ka maagiat ehk tehnikat, mida valdav inimene suudab ületada kõik ümbritseva maailma takistused (Danmann 1995: 9) ja mis on usundis olulise rolli kandja, on jagatud passiivseks ja aktiivseks. Esimese puhul püüab inimene välisnähtusi mõjutada, teise puhul kasutab neid ennustamiseks ehk tulevikujärelduste tegemiseks (Loorits 1940: 2). Aktiivne ennustamine eeldab maagilisi toiminguid, mistõttu Juha Pentikäise järgi saab rääkida eraldi endemaagiast, mille puhul endeid jälgitakse ja loodetakse nende täitumist (Pentikäinen 1987: 74). Émile Durkheimi järgi on maagia eesmärgid individuaal- 
sed. Anna-Leena Siikala täiendab seda seisukohta: see on inimeste pürgimus oma elu kontrolli all hoida (Siikala 1996: 12-13).

Ka käesolevas käsitluses on eristatud aktiivset ennustamist, mis põhineb sihipärasel tegevusel eesmärgiga hankida informatsiooni surma aja, haige saatuse vm kohta, kasutades teatud abivahendeid ja meetodeid, ning passiivset ehk vaatlusel põhinevat ennustamist, mille puhul jälgitakse ehk vaadeldakse (ja/või kuuldakse) märke kust neid endeid siis ka ei leita - ise neisse aktiivselt sekkumata. Järgnevalt ongi eesti materjali põhjal käsitletud kaht erinevat ennustamisvormi. Üksikud alaosad on omakorda jaotatud väiksemateks temaatilisteks üksusteks.

\section{Passiivne ennustamine}

Seesugused ended kehtivad nii haige kui ka terve inimese kohta. Vaatlemisel põhinevaid surmaendeid on käesolevas käsitluses liigitatud esinemissituatsioonide alusel, jättes kõrvale ende välised tunnused:

1) eluta loodus ja puud surmaennetena;

2) loomadega seotud surmaended;

3) lindudega seotud surmaended;

4) salapärased hääled surmaennetena;

5) unenäod surmaennetena;

6) surmaended inimese argielust;

7) teisiku kuju surmaennetes;

8) haigega seotud surmaended;

9) surnuga seotud surmaended.

10) üksikteated

Tihti esinevad nad rahvapärase lausekonstruktsiooniga: kui..., siis...; kes..., see... jne, kui ka lihtsalt jutustuse vormis. Viimased on seotud eelkõige teatud nähtuste, esemete, olendite ilmumise või kadumisega inimese tahtest sõltumata, millega animistlik maailmavaade on sidunud surma põhjuse (Allik 1969: 30).

\section{Eluta loodus ja puud surmaennetena}

Surmaended loodusest on üks üldisemaid ennustuste liike, mida on sagedasti seostatud põdurate inimeste surma ohuga, harvem konkreetsete isikute surmaga. 


\section{Tiia Ristolainen}

\section{Ilmastik}

Inimene tunnetas oma olemasolu kaudu sidet loodusega ja seetõttu otsiti loodusest ka endeid - nii ilma- kui ka surmaendeid, mis nt saarte elanikele olid paiguti samastatavad: halb ilm võib merega seotud inimestele saatuslikuks saada (TK 1993, 5 < Saare- ja Hiiumaa). On arvatud, et inimene on teatud aegadel nõrgem, näiteks sügisel sajuste ilmadega ja kevadel teede lagunemise ajal - siis sureb kõige enam inimesi. Põlvast on teade, et sel ajal surevad just põdejad. Ka tuberkuloosihaigetele olevat need kõige ohtlikumad aastaajad. Surmakuuks on nimetatud aprilli, maid, jaanuari ja oktoobrit. Sügisese ja kevadise niiske ja raske õhuga perioodid on vanarahva tähelepanekute järgi eriti haigetele füüsiliselt raske aeg. Kauaaegsed põdejad surevad uskumuse kohaselt kevadel puude lehtimise või sügisel lehtede langemise ajal (TK 1990, 4 < LääneVirumaa). Ennustati, et kui sügisel lehed puusse jäävad, sureb talvel palju inimesi. Samas näiteks tõi 1998. aasta suvi palju ootamatuid surmajuhtumeid, mida meditsiinitöötajad seostasid erakordselt raske õhuga (TK 1998,1 < Tartu). Kliima soojenemise tõttu esineb informantide sõnul suviti praegugi palju ootamatuid surmajuhtumeid.

Halba ilma, tuult, tuisku jne on seostatud looduses millegi ebapuhta ja halva liikumisega. Surmaennustused seostavad sellist ilma erakordsete surnutega. Arhiivi andmetel surevad halva ilmaga vanapoisid, kelle surmast tundvat kurat suurt rõõmu ja sellepärast ka möllavat. Vanatüdruk pidi samuti halva ilmaga surema. Üldine on uskumus, et halva ilmaga sureb kuri inimene, Pärnu-, Lääne- ja Saaremaal nõid või rikas inimene. Halva ilma järgi ennustasid ka liivlased kurja inimese suremist (Loorits 1932b: 180). O. Loorits viitab eelnevate uskumuste puhul indogermaani eeskujule (Loorits 1932a: 40).

\section{Kuufaasid}

Suremise sagedust on püütud määrata kuufaaside järgi. LõunaEestis arvati, et noore kuuga ihub surm vikati teravaks, vana kuuga on see nüri. Viljandimaa ütluse kohaselt: kui noor kuu on seliti, sureb sel kuul palju inimesi. Pärnumaal usuti, et haiged ja põdejad surevad vanal kuul. 
Tiia Ristolainen

\section{Tuli}

Lääne-Virumaalt pärineb kolm teadet vaimu tule kohta, mis kumab kuskil maa ja taeva vahel, on hallikat värvi, laternasuurune ning ennustab sellesse kohta ootamatut (ka vägivaldset) surma. Arhiiviandmetel ennustab soomlastel surma muu hulgas üleloomulik valgus, tulekera. Tühjas majas tule nägemine ennustab surma neile, kes sinna järgmisena elama kolivad, usuti Läänemaal.

\section{Puud}

Eestlased on arvanud, et suured puud on ühenduses siirdhingedega. Nendega seostatakse mitmeid surmaendeid. Arhiiviandmete järgi on üldine uskumus, et aiast ega kodu lähedalt ei tohtinud puud maha lõigata, muidu pidi peremees või -naine surema, sama ennustas puu ootamatu langemine. Hantidel ennustab surma see, kui inimene näeb puu kukkumist (Moor 1998: 22).

\section{Loomadega seotud surmaended}

Loomadega seotud ennustamiste puhul põimuvad siirdhingekujutelmad ja konkreetsed loomad. O. Loorits käsitleb siirdhingedena mõningaid loomi, linde ja putukaid (Loorits 1932a: 51), kuid - nagu eespool öeldud - on rahvausundis ka suuri puid arvatud siirdhingedega ühenduses olevat. Kui puu maha raiuti, usuti, et hing siirdub edasi, võttes kas looma või linnu kuju, millisena ta edaspidi kodu läheduses hulgub. Ka erakordse linnu või looma tulek maja lähedale tähendas, et hingedele tuleb täiendust ja nad tulevad seda vastu võtma. Sellel uskumusel põhinevadki mitmed metsloomade, pisinäriliste ja putukatega seotud surmaended (Eisen 1926: 124-243; Loorits 1932a: 58, 61; Westermarck 1991: 1019). Loom ega lind ei ole iseenesest surmaennustaja, endena on tõlgendatud üksnes tema teatavat käitumist. Surmaennetes ei esine kõik loomad, vaid osa koduloomadest ja osa metsloomadest.

\section{Koer}

Koduloomadest ongi koeraga seotud suurim hulk surmaendeid. Loomade alalhoiuinstinkt kätkeb surmahirmu. Usuti, et koer tunneb ette oma peremehe surma juba siis, kui kaaskondlased seda 


\section{Tiia Ristolainen}

veel ei aima, ja reageerib inimese surmahetkele. Tal olevat võime näha ringihulkuvat isikustatud surma või surnute hingi, mis kuulutasid õnnetust ja surma. Mõnedel Siberi ja Kaug-Ida rahvastel võis ta esineda ka hingeloomana (Mikkor 1996: 171). Koera puhul on surma ennustanud eeskätt tema ulgumine. Ka koerte vingumine surnu kandmise ajal ennustab uusi matuseid (Wiedemann 1876: 461), samuti koerte haukumine matuste ajal. Viimane enne on tuntud soomlastelgi (Vinha-Mustonen 1981: 12). Seejuures on jälgitud taas ulgumise (sama uskumus liivlastel, vt Loorits 1932b: 172) või koera nina suunda: nt setude järgi tuleb surm talusse, kui ulguval koeral on nina maa poole (Väisänen 1924: 210). Hiiumaal on tähenduslik, kui kaks koera kareldes kiriku poole lähe$\operatorname{vad}$ (Köss 1990: 73). Kihnus ennustab surma, kui koer enam jälgi ei leia (RKM II 10, 230 (72) < Kihnu khk - Paul Ariste < Liis Kuraga, 83 a (1947)).

Paljude koerte üheaegne ulgumine võis tähendada terve küla hävingut. Enne abhaaside Türki emigreerumist möödunud sajandi lõpul olevat koerad ulunud pea üle kogu Abhaasia (Mikkor 1996: 171).

Informandid teavad, et hundina uluv koer ennustab lähedaste surma ka tänapäeval (TK 2001, $11<$ Harjumaa).

\section{Hobune}

Hobune oli hinnaline ja teda peeti ka targaks loomaks. Külaühiskonnas jälgiti ta käitumist eriti siis, kui majas oli haige. See on seostatav hobuse asendamatu osaga talumajapidamises. Samuti vedas ta peremeest ja -naist kirikusse, pidudele ja surnuaeda, mis on genereerinud uskumusi, samuti surmaendeid.

Hobusele pöörati arhiiviandmete järgi matuste käigus suurt tähelepanu ning temaga on seotud väga lai valik uskumusi ja endeid. Kui ta ohkas, tähendas see mõne taluelaniku peatset surma. Arvatavasti kajastub siin uskumus surmast kui iseseisvast olendist, kes veel matuste ajal võib loomi mõjutada. Hobusega on seotud ka eestlaste teadaolevalt vanimad kirjapandud uskumused: Henrik kirjeldab oma Liivimaa kroonikas, kuidas vaadati, kumma jalaga loom astub (Henriku Liivimaa kroonika). Pikalt säilis uskumus, et kui puusärki vedav hobune astus esimese sammu vasaku jalaga, pidi saama majast veel matuseid. Selle järgi ennustati ka surija sugu. 
Tiia Ristolainen

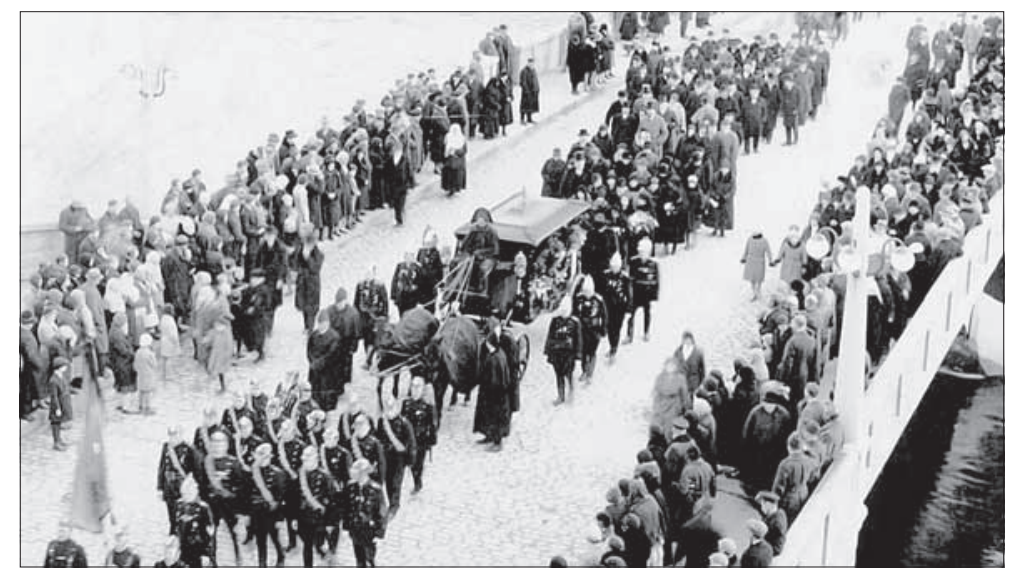

Foto 2. Surnuvankrit vedava hobuse käitumist jälgiti matustel tähelepanelikult - sellest võis välja lugeda surmaendeid. Tuletõrjuja matuserongkäik Tartus Vabadussillal 1931. aastal. Foto Kalju Leiva erakogust.

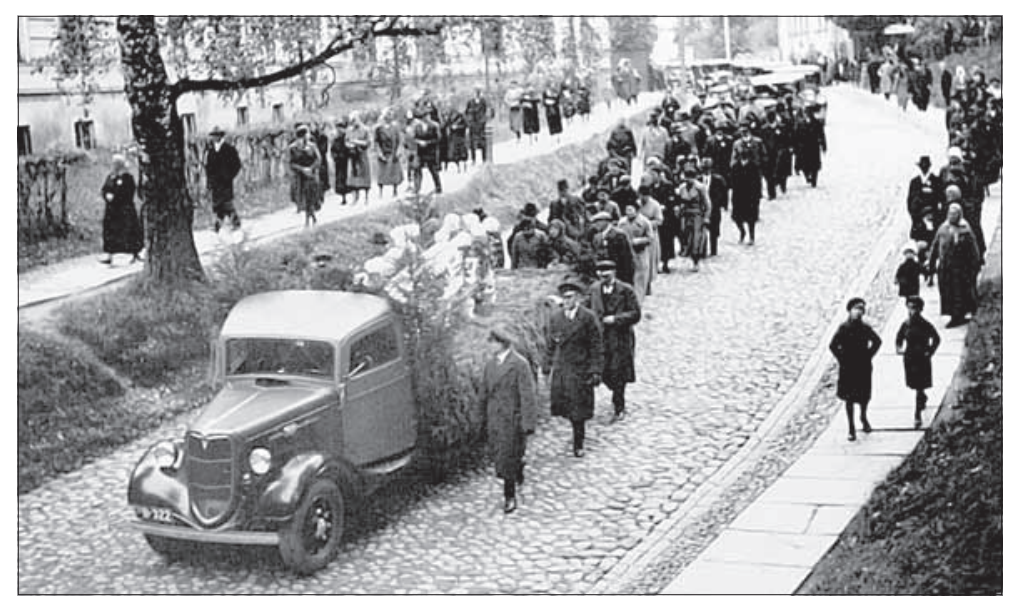

Foto 3. Autoga seotud surmaennetest senini teateid ei ole. Küll aga on tähelepanelikult jälgitud matuserongi. Matuserong Tartus Toomemäel 1930. aastatel. Foto erakogust. 


\section{Tiia Ristolainen}

Uskumusele leidub paralleele soomlastel (Varonen 1892: 94) ja liivlastel (Loorits 1932b: 191).

Kui hobune matuserongis tagasi vaatas, ennustas see mõne matuselise või kellegi surnu omakse surma veel samal aastal. Sama uskumus on tuntud ka soomlastel (Varonen 1892: 94). Kui hobune surnuaeda minnes surnu poole pead pöörab ja hirnub, sureb mõni lähedane sugulane. Hobuse seismajäämine matuserongis tähendas surma. Kui hobused teel mõne maja juures peatusid, ennustati sinna surma. Ka hobuse rakmete lahtiminemine ja hobuse eest ära tulemine oli peatse surma enne, eriti teisele abielupoolele. Samuti tähendasid igasugused muud äpardused õnnetusi - looga purunemine tähendas halba jne.

Surmaennet kandsid ka muud jooned hobuse käitumises teel surnuaeda ja tagasi leinamajja. Hobuse defekatsioon kirstu veokile tõstmise ajal tähendas suguseltsist veel kellegi surma. Sama enne oli tuntud ka liivlastel (Loorits 1932b: 191-192). Kui kirstu vedavad hobused kalmistule mineku ajal hirnusid, eriti kiriku väravas, ennustas seegi surma samas peres. Hobuse komistamine leinarongis, eriti kiriku väravas, oli samatähenduslik ja on samuti seletatav muu hulgas personifitseeritud surmakujutelmaga. Hobuse puristamine koduõues või kellegi maja juures ennustas sinna surma.

Leinamajja pöördumisel jälgiti hobuse vaatamise suunda: toa poole vaatamine tähendas mõne inimese, lauda poole vaatamine loomade õnnetusi. Lõuna-Eestis võis tähendada surma hobuse kodunt välja vaatamine. Üle Eesti tuntud surmaenne oli noruspäine hobune, mis on ka soomlastel tuntud uskumus (Varonen 1892: 94). 1990. aastatel küsitletud vastasid enamasti, et tundliku loomana leinab hobune peremeest või -naist ja lööb pea seetõttu maha (TK 1990, 4 < Viru-Jaagupi khk).

Kui hobune pärast lahtirakendamist kohe püherdama hakkas, tähendas see leinamajja uut surnut. Üle Eesti ennustas seejuures pea suund, kas järgmine surm on tulemas (hobuse pea värava, kiriku või surnuaia poole) või mitte (pea toa poole). Matuselise hobuse püherdamine ennustas surma tema majja.

Tänapäeval on hobusega seotud ennustused aktuaalsuse minetanud, sest tööloomana kasutatakse neid maamajapidamises vähe. Surnu ärasaatmisel on kasutusel eeskätt auto, millega seotud surmaendeid ei ole artikli autor vaatamata küsimisele kuulnud. 
Tiia Ristolainen

\section{Kass}

Rahvausundis halva endena tuntud musta kassi üle tee minek on seni aktuaalne halb enne, mis ei pruugi sugugi ainult surma tähendada. Surmaennetes on ta analoogia alusel asendunud ka teiste loomadega: jänese, rebase, hundi või seaga. Kui need loomad leinarongi ees üle tee jooksevad, on oodata uusi matuseid. Ka see, kui inimene mõne loomaga leinarongile vastu tuli, tähendas lähemal ajal uut surma tegemist on üle tee mineku (teelõikamise) motiiviga.

\section{Arad metsloomad}

Virumaal on arvatud, et kui arad metsloomad, nagu jänes, nirk, orav, hirv, inimese lähedale tulevad, sureb see varsti ära (ERA II 153, 267 (3) < Haljala - Hermann Länts (1937)). Rahvapärane selgitus sellele on, et inimese hingejõud on nii nõrk, et isegi arad loomad ei karda teda enam (TK 1998, $1<$ Tartu). Rootsis ja Soomes usutakse, et orava õuele tulek ennustab tulekahju või surma (VinhaMustonen 1981: 13).

\section{Mutt}

Virumaal levinud uskumuse kohaselt tähendas mutimullahunnik kellegi maa peal maja lähedal surmajuhtumit seal peres. Toa põranda all uuristamine märkis kiiret surma. Võimalik, et siin on tegemist rahvapärase analoogiaga: mutt kaevab mulda - surnule kaevatakse hauda.

\section{Hiir ja rott}

Rahvusvaheliselt on surmaennustajatena tuntud hiired, harvem rotid (Eisen 1926: 234). Hiired ennustavad surma sellele, kelle riideid nad söövad. Iisakus on arvatud, et rottide ärakadumine hoonetest ennustab hävingut (H II 7, 771 (43) < Iisaku khk, Tudulinna vDietrich Timotheus (1889)), mis on ilmselt seostatav ütlusega rotid põgenevad uppuvalt laevalt. Ka Kaukaasia eestlased tunnevad närilisi surma ettekuulutajatena (Mikkor 1996: 170).

\section{Uss}

Külaühiskonnas usuti, et ussi nägemine maja ümber näitab tulevast hävingut või surma. Ilmselt on siin seoseid kodu-või majaussi 


\section{Tiia Ristolainen}

motiiviga. Eesti rahvausundi järgi arvati igal majal olevat oma kaitsehaldjas, kes võis esineda muu hulgas ussi kujul (Valk 1998: 499). Musta ussi ilmumine maja juurde on ennustanud surma ka Soomes (Vinha-Mustonen 1981: 14).

\section{Ämblik}

Must ämblik tähendab Põhja-Eesti uskumustes enamasti muret, õnnetust või surma, kusjuures olulist rolli mängib tema nägemise aeg. Häälikuanaloogia alusel tähendab lõuna ajal ämbliku nägemine leina (Hiiemäe 1997-1998). Üksikuid teateid on Ida-Virumaalt selle kohta, et roheline ämblik ennustab inimese peale laskudes surma. Ämbliku surmamine toob õnnetust, neid on seostatud eesti rahvausundis siirdhinge kujutelmaga. Samas aga üksikute teadete kohaselt on soovitatud ämblik surmaende neutraliseerimiseks hoopis tappa (Köss 1990: 74).

\section{Putukad}

Arhiiviteadete järgi ennustavad surma mitmed putukad, mida vanemas rahvausundis on seostatud eelkõige hingelooma kujutelmaga - eesti uskumuste järgi võis hing irduda elava inimese kehast ja liikuda ringi muu hulgas mõne putuka kujul.

\section{Sitasitikas}

Sitasitikas, nagu mitmed teisedki tiivulised, on samuti olnud seotud teispoolsusega. Suhtumise kujunemisel on kaasa mõjunud mardika must värvus ning maamulla ja kõige maast kasvavaga seotud eluviis. Selili sitika nägemine tähendas haigust või surma, maasse kaevuva või surnud sitika nägemine matuseid (Hiiemäe 1997-1998).

\section{Toonesepp ja toonetikas}

Toonesepa ja toonetikase nimed viitavad toonelale. Toonesepa tiksumine hoonetes assotsieerub sepavasara või rähni toksimisega (tikas tähendab rähni). Nende tiksumine mõjub nagu kellegi elupäevade loendamine. M. Hiiemäe järgi on tiksumist käsitatud surmaendena eelkõige Põhja-Eestis, aga mujalgi. Samuti võis see ette kuulutada kadu, hävingut, haigust, ärakolimist. See 
on otsekui maa-aluste asukate märguanne maa peal elavatele. Kujutlus tooneseppadest sulab Põhja-Eestis ühte kujutlusega maa-alusest rahvast. Virumaal on kujutelm maa-alustest seostunud toonesepaga, seevastu Hiiu- ja Saaremaal, vähem LääneEesti mandriosas - liblikaröövikuga, keda nimetatakse mailaseks (Hiiemäe 1997-1998).

\section{Liblikad}

Liblikate puhul määrab M. Hiiemäe järgi ende sisu värvisümboolika ja nimetuses peituv häälikuanaloogia. Must liblikas tähendab muret ja leina (Hiiemäe 1997-1998). Leinaliblikat iseenesest kohtab harva ja teda suures osas ei tuntagi. Ennustamise seisukohast on oluline just kevadel esimese liblika nägemine.

Lugesin just Eesti Rahva Muuseumi aastaraamatut ja nägin seal M. Mikkori artikli juures leinaliblika pilti. Imestasin, et leinaliblikas on hoopis kirju, mitte must. Pilt sööbis mulle mällu. Mõni aeg hiljem olin maal suvekodu juures ja nägin ehmatusega, et seesama leinaliblikas maandub rohule. Mõtlesin paaniliselt, kas ma olen sellel kevadel enne mõnda liblikat näinud või on see esimene. Mul oleks olnud kergem, kui ma ei oleks seda raamatut lugenud, mõtlesin. Leinaliblikas ei andnud mulle rahu. Umbes paari nädala pärast sain ootamatult onu surmateate (TK 3, $2002<$ Tartu).

\section{Koiliblikas}

Koiliblikat peetakse rahvapärimuses ka surmaliblikaks. Tähenduslik oli tema lendamine inimese peale. Arhiiviteadete järgi oli surmaendeks ka see, kui koiröövik sõi elava inimese rõivaid.

\section{Sipelgad}

Sipelgaid on M. Hiiemäe järgi peetud üldiselt hea õnne märgiks. Teisalt käsitati nende ilmumist inimeste territooriumile kui halba ennet ning tõlgendati ärakolimise, äparduste, haiguse, isegi surma ettekuulutusena. Üksikjuhtudel on selles nähtud ka karistust sipelgapesa lõhkujale (Hiiemäe 1997-1998). 


\section{Tiia Ristolainen}

\section{Kärbes}

Kärbse lendlemist toas talvisel ajal on arhiiviteadete järgi peetud mitmel pool surmaendeks.

Välitööde ja küsitluste põhjal võib väita, et tänapäeval on siiski enimlevinud loom, kelle vastava käitumise järgi surma ennustatakse, koer.

\section{Lindudega seotud surmaended}

Eesti rahvausundis esinevad linnud kui surnute hingede kehastused, mis on mõjutanud ka konkreetsete lindudega seotud uskumustikku. Eesti pärimuse järgi saabuvad hingelinnud teispoolsusest. Kontakt surmariigist tulnud linnuga mõjutab otseselt inimesi. Eriti ohtlikud on need linnuliigid, kellega surnuteusus seondub rikkalikumalt uskumusi kui teistega (kägu, sookurg). Kütikultuurist pärit arusaama kohaselt peab inimene saaklooma ennetama, selleks et temast üle olla (Hiiemäe 1996: 10-13).

Lindude ilmumist haige maja lähedusse on peetud surmasõnumiks (Eisen 1926: 110; Loorits 1932a: 51). Erilise tähenduse omandavad just teatud kindlad linnud (Vernaleken 1859: 104), kellest eesti pärimuses on enim teateid käo, kaarna, varese jt kohta. Tänapäeval tähtsustatakse kelleltki kuuldud või loetud endelisi märke lindude kohta.

\section{Vares}

Virumaal ja mujalgi on kutsutud musti linde surmalindudeks, sest nad ilmuvad alati parves enne katku, loomataudi, viljaikaldusi. Ilmselt on silmas peetud eelkõige musta varest ehk künnivarest, kes on kultuurmaastike elanik. Teda ei eristatud tihti harilikust varesest. Elamute lähedusse ilmumisega ennustas ta halba, sh surma. Üldiselt on vares endelinnuna Põhja- ja Lääne-Eestis halvema mainega kui mujal (Köss 1990: 82). Must lind ennustab surma ka soome rahvausundi järgi (Simonsuuri 1947: 33; VinhaMustonen 1981: 6). Kui kägu oli inimeste petjana tuntud, siis vares sai petta ainult kindlatel päevadel: suure reede hommikul Lõuna-Eestis ja paastumaarjapäeva hommikul Saaremaal (Köss 1990: 83). Mall Hiiemäe andmetel peetakse varest vähem surma 
ennustajaks, küll aga surmasõnumi vahendajaks (Hiiemäe 1996: 15). Artikli autori isikliku kogemuse kohaselt on tänapäeval ka teistsuguseid andmeid.

Umbes kuu aega enne oma ema surma käisime koos temaga Tõrma kalmistul Rakveres, kuhu on maetud mu isapoolsed vanavanemad, isa ja mitmed sugulased. Ema tahtis millegipärast just kiirel kevadtööde ajal Tartust sinna sõita. Ta läks surnuaial peale omaste haudadel käimist veel ühe sugulase hauale ja kadus seejuures tunniks ära. Surnuaed on küllaltki suur ja teda ei paistnud kuskil. Hü̈̈da on sellises paigas ju sobimatu. Pean ütlema, et sattusin mingil määral paanikasse. Seisin ema elukaaslasega vanavanemate haual, kui korraga prantsatas kuskilt ülevalt sinna platsile surnud must vares. Ehmatasime kõvasti. Ema elukaaslane küsis: "Mis see küll tähendab?" Mina ainult mõtlesin vaikides sellele ja pü̈̈dsin endale sisendada, et see ei tähendagi midagi ja surmaendeid uurides ei tohi ma ometi ise kõigele endelist tähendust leida. Halb tunne aga püsis. Lõpuks tuli ema, kes ütles, et ta eksis surnuaeda ära ja sugulase hauda ka üles ei leidnud. Samas oli ta rahul, et oli saanud üle pika aja Rakvere surnuaias käia. Kui ema juulis ootamatult suri, oli mu esimene mõte: must vares ja surnuaeda eksimine seda ju ennustasidki (TK 2001, $1<$ Tartu).

\section{Harakas}

Harakas ennustab eesti rahvausundi järgi surma, õnnetusi ja kohtuskäike - halba. Surmaga seotud endeid on rohkem Lõuna-Eestist, vähem Virumaalt (Köss 1990: 81). Harakad ennustavad siis surma, kui lendavad kellegi aiapostile või maja ukse ette. Ka tänapäeval tähendab haraka häälitsemine õuel surmateadet (TK 2001, $3,11<$ Võrumaa).

\section{Hakk}

Hakkide ilmumist külasse, elumajade lähedusse, häälitsemist ja lendamist maja kohal on peetud surmaendeks kõikjal, v.a KaguEestis (Hiiemäe 1996: 14; Köss 1990: 83). Virumaal on arvatud hakkide maja katusel riidlemisest, et sureb paarisrahvast. M. J. Eiseni järgi kuulutab haki lendamine kiriku poole, kus muidu neid ei pesitse, kellegi tähtsa isiku lõppu (Eisen 1926: 272, 277). Surmaennete 


\section{Tiia Ristolainen}

puhul tuleb peatuda veel ühel hakkide eriliigil - need on naagid ehk kirikuhakid, kes on oma nime saanud lemmikpesitsuskoha - kiriku -järgi. Endelinnuna on nad surma ettekuulutajad (Köss 1990: 84).

\section{Kaaren ehk ronk}

Kaaren ehk ronk on kõige halvaendelisem mustadest lindudest. Nende üle katuse lendamine ja häälitsemine ennustab surnuid. Kaarnad ennustavad just sugulaste surma.

\section{Kägu}

Kägu on rahvusvaheliselt tuntud surmasõnumite tooja nii haigetele kui ka tervetele. Tema kohta on ka surmaennustajana enim rahvapärast materjali. Käo kukkumiste arvu järgi loeti elada jäänud kuid või aastaid. Kägu surmaennustajana on tuntud ka teistel rahvastel. Näiteks sakslased ennustasid kevadel käo esimese kukkumise põhjal nii palju eluaastaid, kui mitu korda kägu kukub. Sama uskumus on tuntud ka slaavlastel ja liivlastel (Loorits 1932b: 171), rootslastel ja soomlastel (Vinha-Mustonen 1981: 7). Laplased uskusid, et kui kägu kaevukoogu otsas kukub, sureb kas peremees või perenaine. Kui ta kukub loomalauda peal, sureb loomi (Qvigstad, 1920: 54). Ka Kaukaasia eestlastel on kägu surmalinnuna tuntud, kuid mitte nii hästi kui öökull (Mikkor 1996: 169).

Vana ütlus edastab: ilmub kägu lehte, tuleb leina-aasta. Hommikul kukub hoolekägu, sööma ajal surmakägu, lõuna ajal leinakägu, õhtul õnnekägu (Eisen 1926: 262). Käo kukkumist maja lähedal tõlgendatakse äkilise surma ennustajana nt Virumaal ka tänapäeval (Köss 1990: 78). Eestist pärineb suurem osa teadetest käo kukkumise kohta surmaennustajana lõunapoolsetelt aladelt, vähem Läänemaalt. Teadetes hoiatatakse ka käo petmise eest: inimene, kes hommikul söömata linnulaulu kuulis, sai petetud, mis tähendas talle mitmesuguseid õnnetusi. Kägu oli eestlastele üheks kardetumaks petjaks, sest temaga on seostatud igasuguseid ebameeldivaid endeid, samuti sellepärast, et käo heledahäälne kukkumine kostis ka läbi kinnise akna tuppa. Linnu ebatavaline häälitsus on olnud üheks põhjuseks, miks teda selliste ennustustega on seostatud (Köss 1990: 79).

[---] Kuulen äkki käo kukkumist. Et kambri aken oli lahti, kostis käo kukkumine selgelt ja valjult kambrisse. [---] Ema, kes 
oli väljas toimetamas, tuli käo kukkumise ajal täis ämbritega kaevult, kuulis käo kukkumist, sülitas kolm korda üle vasaku õla ptühh-ptühh-ptühh! ja lausus: "Ena, reo, lendab mede õue, ei tea, kelle surma ta õege ette kuulutab!" [---] Kümme päeva hiljem, s.o 23. juunil 1920. a tuli tolleaegne kooliõpetaja Madis Oviir meie peresse tõsise näoga. Istus toolile, pani prillid ninale, võttis taskust paberi ja pärast mõnesõnalist sissejuhatust luges: "Pärast võidukat Vabadussõja lahingute läbitegemist suri teie poeg Jüri Oviir Tartu sõjaväelaatsaretis tüüfusesse.” [---] Jüri Oviir (1899-1920) maeti Tartu Pauluse surnuaeda. [---] Minu odde Liise Voore, kes käis ka matustel, rääkis: "Just sama päeva, s.o 13. juuni 1920. a hommikupoolikul - sina vist magasid sel ajal ja ei kuulnud-lendas kägu karjamaa poolt ja otsekohe meie õunaaeda Jüri õunapuu otsa (kui laps ristiti, valati pärast ristimise vesi aeda ühe noore ôunapuu peale. Igal lapsel oli oma õunapuu aias. Sellest ka nimi: Jüri õunapuu). Kukkus seal kolm korda ja pani siis kohe teeotsa poole edasi. Just see tähendaski vend Jüri surma. Vaata, mis käo kukkumine tähendab. Surma kellelegi”(TK 1990, 1-4 < Viru-Jaagupi khk).

Artikli autori kogutud tänapäeva surmaennetest moodustab käo kukkumisega seotu olulise osa - maal ei ole ju käo kukkumise kuulmine kuigi ebatavaline. Selle järgi ennustamine on püsinud pärimuses. Informandid meenutavad vanemate räägitud endeid ja jutustavad viimaste aastakümnete surmajuhtumitest, mille eel on käinud käo tähenduslik kukkumine.

\section{Vainukägu}

Vainukägu on just varasemas usundis tuntumaid surmaennustajaid, sest ta on seotud surnuteriigiga ja tema häälitsemine ennustab surma (Hiiemäe 1996: 18). Niisiis on ta toonela ja hukatuse lind, kes kannab nimetusi surma-, surnukägu, toone-, toonikägu, toonetutt, vaenu-ja vainukägu (Mäger 1969: 112).

\section{Öökull}

Öökull on rahvusvaheliselt tuntud surmakuulutaja. Teda peetakse tumedate jõudude kehastuseks, samas ka tarkuselinnuks. Sakslased usuvad, et öökull hüüab: "Komm mit!" ("Tule kaasa!") (VinhaMustonen 1981: 10). Öökulli häälitsemine elumaja lähedal tähen- 


\section{Tiia Ristolainen}

dab halba ja võib ennustada ka surma. Kaukaasia eestlaste seas ongi M. Mikkori teatel öökullist kui surmalinnust enim teateid (Mikkor 1996: 168).

\section{Kodulinnud}

Kodulindudest võis surma ennustada kana. Kana sabaraputamine ennustas surma kana omanikule. Ka kuke käitumises leiti surmaendeid: kui kukk kires surnu majast väljaviimise ajal, ennustas ta uut surnut. Eesti rahvausundis on kukel oluline roll. Tema laul lõpetab öösel vaimude tunni. Kukke on seostatud üleloomulike jõududega ja matuserongis jälgiti, kelle peres kukk laulab, sealt saab järgmisi surnuid. M. J. Eiseni järgi saab meesterahva surmasõnumeid, kui kukk sirutab jala kiriku poole (Eisen 1926: 277).

\section{Muud linnud}

Üksikjuhtudel ennustab tänapäevalgi surma kajakaparvede ilmumine sisemaale, sookure lendamine maja kohal, rähni (Kirde-Eestis kirju surmarähni ehk toonetikka) tegutsemine maja lähedal, luige laulmine, tihase häälitsemine Kagu-Eestis elamute lähedal või Ida-Eestis maja vahetusse lähedusse ilmumine (Hiiemäe 1997a: 7; 1997b: 7-14). Tänapäeval on üksikuid teateid, et rasvatihase koduaknale koputamine võib ennustada surma (TK 2001, $10<$ Võrumaa). Toonekure seos surnuteriigiga tuleb esile uskumuste varasemas kihistuses, eriti Lõuna-Eestis. Uuemates uskumustes on ta lasteõnne tooja (Hiiemäe 1997c: 17-18). Samuti seostatakse igasuguse linnu tuppa lendamist surmasõnumite toomisega (TK 1998, 1 $<$ Tartu). Autojuhid kardavad lindude aknasse lendamist, pidades seda õnnetuse märgiks (TK 2000, $2<$ Tartu).

\section{Salapärased hääled surmaennetena}

Salapäraseid, ratsionaalse seletuseta hääli tõlgendati ettekuulutusena. See aktualiseerus, kui majas oli haige. Sel juhul seostati iga märki läheneva surmaga ja otsiti neile tähendusi. Niisuguste uskumuste tekkepõhjuseks võib olla kujutlus personifitseeritud surmast: Surm on kuskil lähedal luuramas ja annab endast märku. 
Leea Virtanen on jaganud surmaendena tõlgendatud salapärased hääled nelja rühma: inimhääled, kontakthääled (nt sammud, telefoni või uksekella helin), müra (paugud, kolinad) ja sümboolsed hääled (Virtanen 1977: 116). Antud jaotus sobib hästi ka eesti materjali puhul.

\section{Inimhääled}

Tundmatu päritoluga müra ja hüüdeid on sageli seostatud kujutelmaga isikustatud surmast (Eisen 1919: 49; Loorits 1927: 4-5; Loorits 1932a: 94-95). Üldiseks ja väga levinud surmaendeks on, kui inimest hüütakse nimepidi. Hüüdjat on seostatud personifitseeritud surmakujutelmaga, varem ka nt mütoloogiliste haigustega. Sellisele hüüdmisele ei tohtinud vastata - vastaja usuti surevat. Tänapäevalgi on see uskumus elujõus nii Eestis (TK 1990, 5 < LääneVirumaa) kui ka Kaukaasia eestlaste hulgas (Mikkor 1996: 171172). Ka salapärane nutuhääl ennustas arhiiviteadete järgi mõnikord surma.

\section{Kontakthääled}

Personifitseeritud surmakujutelmaga on seotud ka salapäraste koputuste kuulmine, kusjuures läheduses ei ole teisi inimesi. Eesti Rahvaluule Arhiivis leiduvate teadete ja autori kasutuses oleva ainese põhjal võib seda pidada eesti levinuimaks surmaendeks. Illustreerimiseks on siinkohal esitatud mõned näited:

Kui mitu korda koputamist kuuled, siis kas nii mitme päeva, kuu ehk aasta pärast peab seal surma tulema [tuttavate hulgas] (RKM II 348, 345 (47) < Äksi khk, Tabivere v, Kõduküla k - Anu Korb < Amanda Pääsukene, 82 a (1980)).

Kaks aastat tagasi [1988. a] uppus Moskva lähistel minu õe Salme poeg jões supeldes, saime seda hiljem teada. Aga sellel ööl, kui päeval õepoeg uppus, koputati kõvasti meie aknale. Oli ilus vaikne juunikuu öö. Tõusin ülesse ja läksin aeda vaatama, kes koputas. Oli ilus vaikne suveöö. Ükski koer ei haukunud ja ükski leheke puu otsas ei liikunud, kedagi kusagil ei olnud. Ju Kalle vaim andis enesest märku, et teda enam ei ole. Koputus tähendab alati surma (TK 1990, 1-3 < Viru-Jaagupi khk). 


\section{Tiia Ristolainen}

Koputamine surmaendena on rahvusvaheliselt tuntud, nimetan siinkohal näitena sakslasi (Meyer 1884: 138) ja soomlasi (VinhaMustonen 1981: 18). Koputamist tõlgendavad surmaendena ka Kaukaasia eestlased (Mikkor 1996: 171). 1990. aastate välitööde ja intervjuude käigus räägiti koputamisest surmaendena palju, mis osutab selle uskumuse aktuaalsusele ja isiklikele kogemustele sellega seoses ka tänapäeval. Üks informant on koguni lisanud, et kahel korral on üsna ruttu koputamise kuulmisele järgnenud surmaende täitumine (TK 1990, 1 < Viru-Jaagupi khk). Informant Hiiumaalt kinnitas, et enne mehe surma kuulis ta, kuidas vastu maja klopitakse, mõtles, et naabrinaine hüüab teda piimale. Siis läks voodi juurde tagasi ja kuulis, et keegi hüüab teda kolm korda nimepidi. Mõne aja pärast mees surigi (TK 2000, $3<$ Hiiumaa).

Tänapäeval on pärimusse lisandunud tähenduslik uksekella või telefoni helin, kus vastama minnes ei leita või kuulda helistajat (TK 1998, 2 < Tartu, Rakvere). Ilmselt on koputamise analoogial kujunenud uued surmaended. Sellistest juttudest on ilmnenud, et informandid tõlgendavad neid endena retrospektiivselt, pärast konkreetset juhtumit.

\section{Müra}

Igasugune kolin paigas, kus kindlasti kedagi ei pidanuks olema, ennustas peatselt saabuvat surma, oli see siis millegi ümberkukkumise või mahaloopimise müraga sarnanev hääl. Analoogseid teateid leidub laplastel (Qvigstad 1920: 53) ja soomlastel (Simonsuuri 1947: 35). Eesti pärimusele on olnud varem üldiselt tunnuslik, et laest lubja või seinalt pildi kukkumine ennustab surma suguvõsas. Tähenduslik on olnud ka uste iseeneslik avanemine, Usuti, et surmast võib märku anda lae peal kõndimise hääl (kõndijat ei nähta!), öised tavatud sammude kuulmised ja olematu vankri õue sõitmine müra.

Väga levinud oli salapärase lauakolina kuulmise interpreteerimine surmaendena, mis on arhiivimaterjali põhjal olnud üldine ja levinud ka nt lapi (Qvigstad 1920: 53) ja liivi rahvausundis (Loorits 1927: 5). Reaalselt võimatu lauakolina kuulmine ennustab tänapäevalgi surma (vt nt setu pärimuses - Vassiljeva 1996: 227). On loogiline, et lauasaagimist lakas (19.-20. sajandil varuti kirstumaterjal varem valmis) interpreteeriti kui puusärgilaudade valmispanekut ja saagimist. Analoogiliselt on tõlgendatud puuraiumise kuulmist (vrd soome pärimuses Vinha-Mustonen 1981: 18). Muudki hää- 
led majas, näiteks seinte või põrandate naksumine, usutakse tänapäevalgi surma ennustavat. 2000. aasta lõpul jahmatas eestlasi noore naise surm koerte puremise tagajärjel. Surnu ema rääkis hiljem ajakirjanikele kummalistest ennetest, mis teda pool aastat enne traagilist juhtumit jälitasid:

"Juba suvel hakkas nii minu kui ka Marje toa põrand kummaliselt praksuma, ikka raks-raks ja raks-raks. Nagu oleks põrand vajunud [---]," seletab Helju [ohvri ema - toim] (Jakobson 2000).

Ta meenutas veel kummalist mütsatust esimesel korrusel, pärani uksi jms, mida hiljem surmaennetena tõlgendas (Jakobson 2000).

\section{Sümboolsed hääled}

Teiste inimeste surma eel on kuuldud arhiiviandmete põhjal kellukese helinaid, torupilli mängimist või imeilusat pillimängu, ilusat lauluhäält, soigumist, matuselaulu jm. Salapärased helid on ennustanud surma ka Soomes (Simonsuuri 1947; 34, 37; Vinha-Mustonen 1981, 18). Ka iseenesest helisevad kirikukellad võisid olla surmaenne. Arhiiviteadete järgi arvati, et kui kirikutornis kell heliseb, sureb tähtis isik. Carl Meyer on avaldanud ühe varasema uskumusteate: enne Gustav Adolfi surma Stockholmis olevat nähtud linna kohal naise kuju ja üle kogu Soomemaa olevat kostnud kirikukellade helin (Meyer 1884, 139-140). Tähenduslik oli ka, kui kaugele kirikukell kostis, samuti kuulati sümboolseid helisid kindlatel aegadel. Vadjalased panevad jaaniööl kõrva vastu maad ja kuulatavad, kas ei kosta kirikukella helin, mis ennustab surma (Ariste 1969: 83). Arhiiviteadete järgi on surmaenneteks olnud igasugused nutu- ja kaebehääled. Usuti, et surm tuleb majja, kui ahi või uks nutab või on merelt kuulda nutuhäält. Sama ennustas, kui kohvitass virises, kui sinna kuuma vedelikku kallati. Kiunuv hääl kellamehhanismis ja valed tunnilöögid olid sama tähendusega. Üldse seostati kella kui ajasümboli segiminekut inimese elu kestmise ja peatumisega.

Salapärastest häältest on surma tähendanud veel iseäralik hääl, sea röökimine, põrsa kiljumine, puu kukkumise ragin, tiksumine majaseintes, metsakohin. Oskar Loorits mainib, et neid hääli kuulatati peamiselt surnu valvamise juures (Loorits 1949: 76), sest oli tähtis ennustada suguvõsa järgmist surmajuhtumit ja selleks valmis olla. Tähenduslik oli veel seos tulega: kui kolde leek vurisedes põles või 


\section{Tiia Ristolainen}

kui teekann vilistas, pada tulel pirises või puud pliidi all visisesid, saab vaeslapsi. Viimasel ennustusel on paralleele lapi rahvausundis (Qvigstad 1920: 52). Arhiivimaterjali järgi oli oluliseks aspektiks häälte kuulmise juhuslikkus.

Osa salapäraseid hääli on eesti rahvausundis seostatud maa-alustega. On arvatud, et maa all elab rahvas, kel on samasugune elukorraldus nagu maapealsetelgi. Neil on oma sepapajad ja kui nende raua tagumise kõlin või ketramishääled üles kostavad, ennustab see surma. O. Looritsa järgi on maa-aluste usk tulnud germaanlastelt ja Eestis kodunenud (Loorits 1933: 802). Maa-alustega seotud uskumused on tänapäeval hääbunud ja mainitud ennetele on leitud ratsionalistlikud seletused.

\section{Unenäod surmaennetena}

Unenägusid ei peetud tähenduslikeks üksnes varem, vaid nende üle juureldakse rohkesti ka tänapäeval. Matthias Johann Eisen defineerib und isikustatud vaimseks olevuseks ning tema sõnul on unenägu see, mida hing rändamise ajal näeb (vt Eisen 1926: 123, 254).

Kuna unenägusid peeti hinge reaalseteks elamusteks, hakati neis nägema endeid ja neid seletama. Juba Aristoteles on väitnud, et kuna enamik inimesi arvab, et unenägudel on tähendus, siis loob see usu, nagu oleks jutt kogemustest, ning ei ole võimatu, et mõnel juhul sisaldubki unenäos ennustus (Aristoteles 1992: 698).

Unenägudest on eestlased otsinud muu hulgas ilma- ja surmaendeid, mis on huvitaval kombel tihedalt seotud. Võib peaaegu ütelda, et ilmastikunähtuste järgi ennustati surma ja surnute nägemise järgi ilma. Minu arvates jõuti mitmete seletusteni kogemuste alusel: kui pärast millegi unes nägemist juhtus inimese elus oluline sündmus, näiteks suri mõni lähedane, andis see võimaluse unenäo seletamiseks.

Isiklikult kaldun endeid uskuma. See on unenäost või ilmutusest, mida kogesin 5-aastase lapsena. Nägin selgesti, et minu kallis onu läks purret mööda üle jõe asuvasse väiksesse majja, kust enam ei väljunud. Üsna pea onu suri. Minu vanemad imestasid väga, kuidas laps surma ette aimas (TK 1990, 1 < ViruJaagupi khk). 
Sel juhul seostas inimene unes nähtut reaalsusega: kui keegi läheb kohta, kust ta enam ei välju, tuleb tegemist surmaga. Samas viitavad mõned saartelt kogutud juhtumid ka sellele, et paljud on harjunud Unenägude seletajate abil nähtut tõlgendama, neid ise siiski uskumata:

Aga ega ma neid unenägusid ikka usu, inimesed on lihtsalt harjunud niimoodi tõlgendama. Olid siin igasugused unenägude tõlgendamise raamatud (TK 2000, $3<$ Hiiumaa).

Naabriperes oli hästi palju lapsi ja ükskord ma nägin unes, et seal karjaaias kasvasid sarapuupõõsad, sellised madalad ja pähkleid nii täis, ja ma’i suutnud oodata kuidagi, millas need valmis saavad. Ja järgmine päev sealt pereema tuleb ja ütleb, et peremees jäi haigeks, vii talle neid pähkleid. Siis ta sõi neid pähkleid ja suri ära.

Ja mina rääkisin siis teine päev unenäo teistele, et muidu pärast ei usuta, ja siis mõni ütles, et ah, ära nõiu ja... Ja oligi nii, kolm-neli päeva ja...

Aga ma ei usu seda. Ja siin on niimoodi, et mul on väga palju unenägusid täide läinud. Võib-olla see teeb ka niimoodi, et hakkad uskuma rohkem, kui sul ikka kõik asjad täide lähevad (TK 2000, $3<$ Hiiumaa).

Leea Virtanen toob välja surma ennustavad unenäod soome materjali põhjal: surnutega suhtlemine, kiriku ja reisimisega seotud sümbolid, ruumide koristamine, jahu ja küpsetamine, hamba kaotamine, loodusnähtused (päike, kuu), tulekahju (Virtanen 1974: 92). Tulekahju on unes ühendatud punase värviga, mis tähendab surma. Reisimisega seotud sümbolite all peetakse silmas hobuseid (eriti musti hobuseid), linnuparvi jne (Vinha-Mustonen 1981: 15). Eesti materjali põhjal analoogset jaotust rakendada ei ole võimalik, seetõttu pakun siinkohal välja omapoolse liigituse: igapäevased tööd, surnu ja sant, hääled, kristlikud motiivid, ihuliikmed.

\section{Igapäevased tööd}

Selle alajaotuse ended on arvestatavad ka tänapäeval. Levinud surmaendelistes unenägudes nähakse maa kündmist, analoogilise tähendusega on teised mulla ja maaga seotud tööd nagu kraavi kaevamine ja viljalõikus. Viimastest on arvukalt teateid Lääne-Virumaalt (TK 1990-2000). 


\section{Tiia Ristolainen}

Kui minu isa Siberis suri, nägin unes, et meie kodus Võrumaal oli lipuvarda ümbrus adraga üles küntud (EFA I 61, 59 $<$ Lääne-Virumaa < Kanepi khk - Eevi Jegorov (2002)).

Kündmise nägemisele unes kui surmaendele viitab ka Ave Tupits oma bakalaureusetöös (Tupits 2002: 48).

Unenäod uute hoonete ehitamisest surmaendena on rahvusvaheliselt tuntud (Mikkor 1996: 173). Uue hoone püstitamine unes viitab ka Virumaal peatsele puusärgi tegemisele. Kadrinas usuti, et kui unes pooleli ehitatavat maja nähakse, jääb peres keegi haigeks, kui aga tervet maja, siis sureb keegi ära. Unes majalt korstna langemine tähendab peremehe surma.

Mõni päev enne isa surma nägin unes, et olime õega ehitanud uued majad hästi ligistikku (vast paar meetrit oligi vahe) ja minu abikaasa ja õe abikaasa kaevasid nende uute majade vahele kraavi. Vanade inimeste mälestustest olin kuulnud, et uue maja ehitamine tähendavat surma. Veelgi enam viitas surmale aga unes nähtud maakaevamine. (Kuigi enamus inimesi ei usu unenägudesse, on minu unenäod väga tihti täide läinud ja seetõttu oli mul ka tookord surma ees hirm.) Aga isa ilmselt aimas oma surma ette, kuigi tervisel tal tol ajal midagi eriliselt hullu haigust polnud. Isa näiteks mü̈̈s maha nii lehma kui lambad, sest ütles, et temal neid enam vaja pole. Samuti ütles ta kartulinoppimise ajal, et tema ise neid enam ei müü ja käskis seda meil teha, kusjuures ta väitis, et ka seda raha enam ei tarvita. Ka pü̈̈dis ta ära teha kõik vajalikud tööd nii kodus (näiteks sauna veekatla vahetuse), mis oleksid võinud veel oodatagi, kuid tema väitis, et kui mind enam pole, kes seda siis enam teeb. Siis aga muutus isa tervislik seisund järsku halvaks ja ta tuli haiglasse saata. Arstid väitsid, et süda tahab veidi turgutamist ja et nädala pärast saab ta kindlasti välja. Paari päeva pärast teda aga elavate seas enam polnud (EFA I 61, 165 < Iisaku khk, Iisaku v, Alliku k - Anne Nurgamaa (2002)).

Veel näitavad sellised tavalised tubased tööd nagu toa pesemine ja pühkimine surma, samuti pesupesemine. Ida-Virumaal usuti, et kui inimene näeb end unes pesu pesevat ja sealjuures viib pesu koos veega nõnda ära, et seda enam kätte ei saa, siis tähendab see sur- 
ma (vt nt E 6888 (3) < Vaivara khk, Narva v, Kreenholmi as - J. Laur (1893); H III 1, 635 (39) < Lüganuse khk - Emilie Bachmann (1888)).

Lüpsmistki seostatakse surmaga - saadakse surma sõrmi katsuda.

Puu raiumist on peetud hävingu märgiks. Kuusepuu maharaiumine tähendab meesterahva ja lehtpuu raiumine naisterahva surma. Eriti tähenduslik oli puu raiumine maja lähedalt. Puu murdumine ennustab surma ka tänapäeval.

Nägin unes, et surnud naabrinaine raius maha ja viis ära ilusa väikese kasekese meie maja eest. Tegelikult meie maja ees kaske ei kasvanud. Mina veel ütlesin naabrinaisele, et miks sa nii tegid, kaseke oli ju alles nii väike. Tema vastas mulle, et küll kasvab uus puu asemele. Paari nädala pärast sündinud pojapoeg elas sünnitrauma tagajärjel ainult ühe ööpäeva. Uus puuke - pojatütar - sündis kahe aasta pärast (EFA II 41, 431 $<$ Läänemaa < Nissi khk, Riisipere v, Riisipere k - Erna Šutova (2002)).

Üksikuid viiteid on Virumaalt kangakudumise, vihtade tegemise, vaipade kloppimise kui surmaennete kohta:

Kui ma midagi näen unes, nii on kohe see käes. See on esimene tundemärk, kui keegi klopib. Enne ema surma kuulsin ka kloppimist (TK 2000, $3<$ Hiiumaa).

\section{Hääled}

Unes kellegi hüüdmine või kõnetamine ennustab arhiiviteadete järgi surma. Unenägudes surma ettesõnamine on tuntud ka Soomes (Simonsuuri 1947: 42). Samas väidetakse tänapäeval ka vastupidist:

[---] nimepidi hü̈̈dmise suhtes aga ma ei oska midagi öelda, sest mind isiklikult on aastaid hü̈tud vaikselt eesnime pidi, aga tänase päevani elan (TK 1990, 1 < Lääne-Virumaa).

Samuti ennustavad surma muud hääled, näiteks püssilaskmine. Eesti rahvausundi järgi ei tohtinud unes hüüdmistele vastata. Muidu antakse oma hääles kätkev hing kutsuja meelevalda (Loorits 1932a, 44). Katku ja halli kombel kõnetab ka surm inimesi ja kutsub neid nimepidi (Loorits 1932a: 93). 


\section{Tiia Ristolainen}

Kui jutustaja mees ära surnud, siis näinud ennem unes, et keegi tahtnud püssiga lasta läbi akna. Tema palund vastu, et ärgu lasku. Siis sihtija ütelnud: "Kümme päeva annan sulle aega."-Soo, meil tuleb nü̈̈ surnu, arvatud kohe. - Pea meeles, sul kümme aastat on veel elada, öeldud mehele. Ja mees surnud tõesti kümne aasta pärast ära (ERA II 13, 212 (31) < Simuna khk, Avanduse v, Avanduse k - Richard Viidebaum < Anna Tepu, 69 a (1929)).

\section{Surnu ja sant}

Eestis on levinud uskumus, et kui surnu unenägijale midagi annab, on see hea märk, ja vastupidi. Seda võetakse tõsiselt ka tänapäeval.

Kui unes surnult midagi vastu võtad, on see halb enne (TK 2001, 3 < Harjumaa; TK 1990, 1 < Rakvere).

Keda surnu öösel unes kaisutab, see sureb, arvati Rakveres. Samuti arvatakse tänaseni, kui surnu kedagi kaasa kutsub.

Minu abikaasat kutsusid unenägudes tema manalasse läinud sõbrad mitmeid kordi endi juurde, tema keeldus minemast. Paar kuud enne surma ütles abikaasa, et üks surnud sõber kutsus teda jälle kaasa. Ta olevat lubanud varsti külla minna. Ja läkski... (EFA II 41, 431 < Läänemaa < Nissi khk, Riisipere v, Riisipere k - Erna Šutova (2002)).

Sama enne on tuntud ka Kaukaasia eestlastel (Mikkor 1996, 172 173).

Enne ema surma nägin unes maja, kus ta kunagi elas. Seda polnud varem unes olnud. Siis nägin unes, et emal olid mustad riided seljas ja ta hakkas ära minema, oma kodu poole. Talle tuli noor ilus mees vastu mustas riides. Ta peatas ema ja vôttis tal käe alt kinni ja viis ema ära. See oli minu isa. Isa oli ennem surnud ja nägi tõesti nii välja (TK 2000, 3 < Hiiumaa).

Teeb kadunuke unes mõnda nendest igapäevastest töödest, mis surma ennustavad, sureb keegi sellest majast, arvati Ida-Virumaal. Analoogilised ended on seotud santidega, sest tõlgendustes võidakse surnuga võrdsustada santi, kerjust. Kui sandile unes leiba an- 
nad, tähendab see surmale ohvri andmist. Võõra unes nägemist peetakse üldiselt halvaks endeks.

Ükskord jälle nägin, et üks surnu tuli tee peal vastu ja küsis minu käest teed ühte tallu. Praegu elavad seal uued inimesed. Orjaku külas oli see. Ja ma juhatasin ja... Aga ta ei leidnud või mis tal oli, ja tuli siis uuesti küsima. Ja mina ütlesin, et no tule siia mäe otsa, ma näitan sulle. Läksime sinna mäe nuka peale ja ütlesin, et vaata hoolega, ma nü̈̈d näitan sulle... Ja seal suri hiljem üks inimene ära (TK 2000, 3 < Hiiumaa).

Mõned tänapäevased teated kõnelevad nn vikatimehest, kes ilmub unenäos, ennustades sellega kellegi surma.

Nägin und, mis mind kohutas. Esimene tegu hommikul oli oele ja emalegi sellest rääkida. Uni oli järgmine:

"Olime õega eestoas, kui ootamatult avanes koridorist uks tuppa ja sisse astus surm (nagu teda piltidel olin näinud). See oli luukere, mida kattis pikk tume mantel, peas oli tal kaabulotu ja õlal roostes vikat. Meist möödus ta sõnagi lausumata, läks tahatuppa ning andis emale sinise tservonetsi (väärtus 5 rubla-punane oli 10-rublane). Ka emale ei lausunud ta sõnagi. Tulnud tagasi elutuppa, sõnas ta õele ja mulle: "Ega ma teda praegu ära ei vii, kuid ega ma teda teile kauaks ka ei jäta." Siis võttis ta laua äärest 3 tooli ja lahkus."

Ema ütles seda kuuldes:

"Imelik, kuidas sa võisid küll nii koledat und näha."

Algas 1947. a. Elu läks edasi ja unigi ununes. Jaanuari keskel märkasime õega, et emaga toimuvad mingid muudatused. Ta muutus närvilisemaks, tujutuks ja jumegi kahvatus. Algul ei rääkinud ema meie pärimise peale midagi oma muredest, siis rääkis, et ta ei tunne end hästi ja pesugi on vahetevahel verega määrdunud. Õde läks kohe naistearsti juurde, et kokku leppida, millal ta ema läbi vaadata saaks. Arst aga oli just haigestunud grippi ja vastuvõttu polnud. 2. veebruarist oli arstil jälle vastuvõtupäev, kuid see oli laadapäev, millal alati tung tema juurde. Nii leppisid arst ja õde kokku, et 3. veebr tulgu kell 10 ema tema vastuvõtule. Kui ma 2. veebr hommikul kooli tööle läksin, oli emaga kõik korras, kui lõunaajal töölt tulin, oli ema voodis ja arst tema juures. 


\section{Tiia Ristolainen}

Emal oli alanud verejooks. Avastati vähkkasvaja. Ema sai küll Tartus kliinikus raadiumiravi ja teda kiiritati, kuid midagi ei aidanud. 4. juulil ema suri uriinimürgitusse, sest ta neerud olid lakanud töötamast (EFA I 60, 145/6 < Võrumaa -A. Rinne (2002)).

\section{Kristlikud motiivid}

Kirikuõpetaja unes nägemine on tähendanud surma Lääne-Virumaal ja mujalgi, eriti kui ta kellegi poole koju tuli. Tegemist on suhteliselt vanade ja üksikute teadetega 20 . sajandi esimesest poolest, mis lubab oletada, et uskumused on kuulunud aega, mil kirikuõpetajal oli ühiskonnas oluline roll ja temaga seostati seetõttu erinevaid endeid.

Ka ingli nägemine unes ei kuulu heade ennete hulka.

Jutustaja näind unes, et üks ingel tulnud hommiku poolt, must rist käes, läind üle maja ja kadund õhtu poole (õhus hõljund). Mõne aja pärast surnud säält kaks inimest (ERA II 12, 411 (36) < Simuna khk - Richard Viidebaum (1928-1929)).

Ka tänapäeval teatakse seda surmaennet:

[---] Nägin viis aastat [1985. a - T. R.] tagasi unes, et meie aia kohal taevas oli suur-suur imeilus ingel. Ta oli just sellel kohal, kus Allake armastas pingil istuda. Ingel oli valges rü̈̈s ja ulatas nagu käe allapoole, et just sellelt kohalt midagi noppida, siis ulatas käe teise ja kolmandasse kohta. Esiteks suri meie armas vanatädi, siis üle tee üks vanem naine. Ja selle järel vanem mees. Just nõnda järjekorras, kui ingli käsi liikus. See oli surmaingel [---] (TK 1990, 1 < Viru-Jaagupi khk).

\section{Inimese ihuliikmed}

Arhiiviteadetel märkis unes juuste lõikamine surma, samuti nagu rahvusvaheliselt tuntumaid surmaendeid hamba murdmine (Freud 1995), mille kohta on ka Eestist hulgaliselt teateid.

Üksikuid teateid on Lääne-Virumaalt, et varga ja venelase nägemise ennustab surma. Peakatte kaotamine unenägudes toob leina ja must hobune tähendab surma (Vahtramäe 1992: 28). Viimast 
saab väita ka soome materjali põhjal (SKS). Eestlastel on musta värvi nägemine unes tähenduslik ka tänapäeval:

Kümme aastat tagasi (1990) mu ema ja minia nägid ühel ja samal öol ühesuguse unenäo: oli nagu paat, valge lina peal, terav ots vastu Sarve küla. Lillevaasid olid laua peal. Mõne päeva pärast põles Sarves mees paati. Ema ja minia enne kangesti kartsid, et surm tuleb oma majja. Must värv unes tähendab surma (TK 2000, $3<$ Hiiumaa).

Tänapäevastest teadetest ilmneb, et halvaendelise une nägemise järel selgub üsna peatselt, et keegi on just samal ajal surnud. Inimene nagu tunnetaks alateadvusega lähenevat või samal ajal toimuvat.

Enne isa surma magasin halvasti. Suigatasin ja ei tea, kas nägin unes või ilmsi; kui silmad lahti tegin, nägin, nagu oleks olnud papa näo ovaal. Papa oli haige ka. Telefon helises ja õde ütles, et papa on surnud. Kell oli kolmveerand neli. Võib-olla olid papa mõtted minuga, võib-olla oli unenägu (TK 2000, 3 < Hiiumaa).

Ö̈̈sel nägin unes, et õde tuli koju. Tal olid juuksed lokitud, seljas oma kõige uuem kleit, käes kohver, mille ta põrandale asetas ja siis mulle ütles: "Soo, nü̈̈d olen ma täiesti terve!" Ärkasin selle une peale ja vaadates kella nägin, et see oli 4. Mulle tundus see uni kohutavana. Süda hakkas valutama. Kartsin kõige halvemat. Läksin postkontorisse ja helistasin sealt Tartusse Maarjamõisa haiglasse, et küsida õe tervise järele. Sain teada, et ta suri öösel kell 4 (EFA I 60, $147<$ Võrumaa-A. Rinne (2002)).

Unenäod on tänapäeval enimlevinud ja inimeste poolt tõsiseltvõetavaim surmaennete rühm. Samas on tõlgendusi otsitud ka trükitud unenägude seletajatest. Tundub, et tihti on unenägude tõlgendused hilisema analüüsi tulemused pärast konkreetset surmajuhtumit. Ajaline vahe unenäo nägemise ja täitumise vahel võib olla väga erinev.

Olen kõik surmad ette näinud, see on mul tõest ja vaimust ette nähtud. Ja mul ei lähe rohkem mööda unenäo nägemisest täitumiseni kui kolm-viis päeva (TK $2000<$ Hiiumaa). 


\section{Tiia Ristolainen}

\section{Surmaended inimese argielust}

Mitmeid inimese argieluga, sageli igapäevaste töödega seotud märguandeid tõlgendatakse surmaennetena. Selliste juhtumite võimalikuks ärahoidmiseks kehtisid vastavad käsud ja keelud.

\section{Magamine}

Magamisasenditega on seotud mitu ütlust, mis on samas ka surmaended. Pärimusliikide omavaheline seos on siin raskesti eristatav. Arhiiviteadete järgi on üldine uskumus, et kõhuli magaja upub ära. Virumaal usuti, et kogu aeg unine olemine tähendab surma lähenemist. Saaremaalt on pärit arvamus, et norsates magaja sureb lumeta aastaajal. Viljandimaalt on üles kirjutatud, et õhtul varakult magama minejad surevad ka õhtusel ajal. Põhja-Tartumaal usuti, et silmad lahti magaja sureb ruttu ära. Lapse magamise ajal tuli valvata, et surnurong mööda ei sõidaks, muidu sureb laps ära. Surnu võis magamise ajal kehast irdunud hinge oma meelevalla alla võtta.

\section{Tööd}

Maainimesed on oluliseks pidanud, et kartulivao ots tühjaks ei jääks - see pidi surma tooma. Tänapäevalgi on informandid kinnitanud antud ende tõsiseltvõetavust (TK 2002, $1<$ Põlvamaa, Valgamaa, Lääne-Virumaa).

\section{Leivategu}

Virumaal oli levinud enne: kui leivad ei kerki, tuleb surm peresse. Samuti kui leivategemise ajal leiba pealt siludes läks sõrm kogemata sinna sisse, pidi tulema peres surmajuhtumeid. Kui leib ahju pannes labidalt selili kukkus, tähendas see küpsetaja surma.

\section{Tuli}

Kui öösel tuba valgeks läks nagu päeval, oli see surma märguanne. Vahetult enne surma tulekut on tuld korraks nähtud ka surija peatsis Järvamaal. 
Tiia Ristolainen

\section{Kell}

Oluliseks märguandeks surma saabumisele oli kella seismajäämine. Sama uskumus on tuntud ka germaani rahvastel (Meyer 1884: 138).

\section{Risti kuju}

Üle-eestilise uskumuse kohaselt tähendas põrandale või maha moodustunud risti kuju peatseid surmasõnumeid, oli see siis puupilbastest, ahjupuudest, vitsaraagudest, peerupilbastest või õlekõrtest. Juhul, kui selline rist oli tekkinud kätki alla, ennustas see Ida-Virumaal lapse surma.

\section{Inimese välimus}

Inimese välimusega seondub eesti rahvausundis hulk surmaendeid. Kui vanemal inimesel suu rääkides väriseb, jõud kaob ja nägu kahvatuks tõmbub, ennustab see surma. Setumaal ennustas surma, kui sinine joon läheb lastel üle nina või ninaots tõmbub teravaks. Ennustuse aluseks on konkreetsed tähelepanekud igapäevasest elust. Kui sõrmekü̈̈ned roostetavad, ennustab see surma suguvõsasse. Kui lapsel oli sündides käenahk valge, öeldi, et tal on kalmukindad (surmakindad) käes, mis ennustas varast surma, kuigi leidub ka vastupidiseid arhiiviteateid. Kalmusukkadega sündimine (surisukad - jalapöiad on valged) märkis varast surma. Kui lapsel oli sündides keha valge, nagu oleks särk seljas, tähendas seegi surma, kalmusärki. Selle alarühma surmaendeid on teada kõikjalt, üleskirjutusi on enim Virumaalt.

Tänapäeval võib informantidele tuginedes enimlevinud ennustuseks välimuse järgi pidada järgmist:

Minu ema rääkis juba siis, kui mu vend Sass oli väike poiss: "See laps muud surma ei sure, ta upub ära." Küsisime, et kust ta seda teab. Ema vastas: "See on ju vanarahva tarkus. Need inimesed, kellel on pealael juustes kaks keerdu, need upuvad ära" (ERE 2000: 41).

Edaspidisest selgub, et tolle eluloo autori venna saatus kujunes just selliseks. 


\section{Tiia Ristolainen}

\section{Arvumaagia}

Eesti surmaennetes domineerivad maagilised arvud 2, 3, 7, 13. Usuti, et kui üks kaksikutest ära sureb, läheb ka teine järele, või kui ühest perest kaks inimest suri, arvati, et sureb ka kolmas. Tähenduslik on kolmekordne tegevus: koputus, pauk, linnu häälitsus jms. Seitsme aasta peale ennustatakse ette, et surnu võib kätte maksta ja enesega kedagi manalasse kaasa viia, kui talle korralikke matuseid ei korraldata. Kui kolmteist inimest laua ümber istub, usuti, et üks neist sureb veel sel aastal. Arvumaagiale rajanevate uskumuste puhul on tegemist rahvapärase analoogiaga: kui üks, siis teine; kui kaks, siis kolm on kohtu seadus. Tänapäeval on arvumaagia eeskätt koolilastel tuntud:

[---] kui keegi küsib su käest 25 krooni unes, lahkub keegi omastest 25. kuupäeval (TK 2001, $3<$ Harjumaa).

\section{Teisiku kuju surmaennetena}

Lisaks mitmesugustele märkidele, mis arvatakse surma ette kuulutavat, on oma roll täita ka surmaolenditel, kellest eesti rahvausundis on tuntuim marras ehk mardus. See on põhjaeestilise taustaga surmaolend ja surma ettekuulutaja, kes võis anda auditiivsel või visuaalsel viisil märku lähenevast surmast koputamise, kolistamise, kõnetamisega, ilmumisega mehe, naise, lapse või tundmatu kujul. Ta võis ilmuda ka looma või linnu kujul. Marrase nägemine tähendas selle inimese surma, kelle marrast nähakse. Oma klassikalises usundilises tähenduses on ta elava inimese kehast irdunud hing, kes ilmub nagu surm - vältimatult ja neutraalselt. Oskar Looritsa järgi on tema kujunemine protsess, mis kulges järgmiselt: surnu - irdhing - inimese-ja surmahaldjas - surmaenne (Loorits 1949: 252-255).

19. sajandi rahvapärases materjalis on marras tihti segunenud teiste surmaga seotud mütoloogiliste olenditega, nagu kodukäija või inimese haldjas, mis näitab antud uskumuse tähenduse taandumistendentsi. Enamik arhiiviteateid pärinebki 19. sajandist ja oli juba 20. sajandiks aktuaalsuse kaotanud, mille üheks põhjuseks on ilmselt väike levikuareaal (Virumaa rannik) ja kuulumine suhteliselt vanasse uskumusterühma. Võib öelda, et marrase puhul on tegemist tänapäevaks täielikult kadunud surmaendega. Ükski infor- 
Tiia Ristolainen

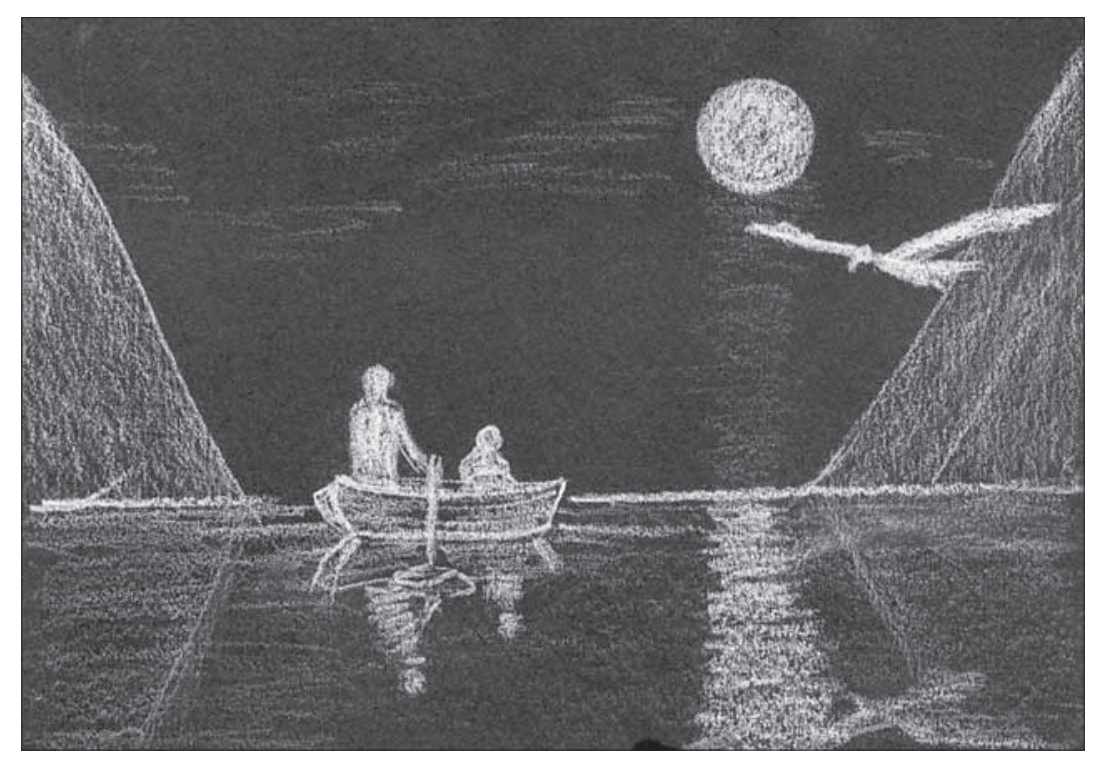

Foto 4. Surmakujutelmad. Mari Peterson 2002. Tartu Ülikooli filosoofiateaduskonna eesti ja võrdleva rahvaluule õppetooli kogu.

mantidest ei osanud marrase kui surmaennustaja kohta seletust anda. Teati küll, et ilmub ajakiri Marras, kus avaldatakse õuduslugusid, ja Tallinnas olevat olnud 1990. aastatel samanimeline laste valmisriiete kauplus, mille nimevalik viitab sellele, et sõna tegelikku tähendust ei teata.

Eestlased on uskunud, et iseenda teisiku nägemine ennustab surma. Sama tähendab, kui must vari tuleb vastu. O. Loorits väidab, et teisiku motiivil ei ole eesti rahvausundis kindlat kohta (Loorits 1949: 253). Samas on eesti surmauskumustes see motiiv tuttav ja laialdaselt levinud. Oma teisiku nägemine tähendab surma nii laplastel (Qvigstad 1920: 54) kui ka sakslastel (Meyer 1884: 138). Tänapäevalgi on informandid rääkinud mitmetest teisikuga seotud juhtumitest kui surmaennetest.

Kuidas mees oma surma nägi. Hakkas mere ääres käima ja nägi, et tema kõrval käib mees, kolmed riided seljas - sinel, leetkuub... Läks merele ja hukkus... Enne rääkis teistele sellest, kuid eks ta tegelikult oma varju nägi (TK 3, $2000<$ Hiiumaa). 


\section{Tiia Ristolainen}

Lääne-Virumaal arvati, et kui tuttavad inimesed teineteist ligidalt ära ei tundnud, siis üks neist sureb. Tänapäeval öeldakse, et saab rikkaks.

\section{Haigega seotud surmaended}

Eesti surmaendeid iseloomustab uskumus: kellele surm on ette määratud, see ei pääse. Ennustustes võib märgata just püüdu surma aja teadasaamiseks. Seetõttu jälgiti hoolega haige liigutusi ja vähimaidki muutusi tema välimuses. Arhiivimaterjali põhjal võib väita, et ennustusi haigele on olnud arvukalt, mis näitab antud surmaennete alarühma tähtsust külaühiskonnas. Surmaennete tajumist on seletatud nii haige kui ka tema lähedaste inimeste psüühilise pingeseisundiga, mis tingivat mitmesuguste heli- ja valgusilmingute jm kogemist (Mikkor 1996: 168). I. Paulson nimetab sellist seisundit ootuslikuks vastuvõtuks (Paulson 1966: 169).

Tänapäeval võib küll täheldada, et ilmselt keegi ei lähe haiget spetsiaalselt vaatama, otsustamaks märkide järgi tema edasielamise või surma üle. Küll on mitmed haigetega seotud surmaended tuntud ka tänapäeval, eriti meditsiinitöötajate ringkonnas. Rahvapärased teadmised liiguvad edasi professionaalidele, mis on üks surmakultuuri arengusuundi tänapäeva maailmas.

\section{Haige liigutused ja välimus}

Eesti materjali põhjal võib väita, et tõeseid andmeid annab vaid haige esmakordne vaatlemine. Pea liigutamine esmakordsel külastusel tähendas mandril surma, Saaremaal vastupidi. Jalgade liigutamine aga elu, sest jalad kannavad. Virumaal oli levinud käte jälgimine. Kui haige esimesena kätt liigutab, on see surmaendeks - annab tööd puusärgi tegijale. Sama uskumus on tuntud eriti Saaremaal seoses jalgadega: kui haige liigutab jalga, tähendab see surma - sümboliseerib ilmselt manalatee algust. Lokaalselt on täpsustatud veel, et haige vasaku käe või jala liigutused tähendavad surma. Ennustuse aluseks on analoogia: vasak (resp. pahem) tähendab halba. Palju on tähelepanekuid, et haige käed ja jalad muutuvad külmaks või rahutuks. Meditsiiniliselt saab seda seletada südametegevuse nõrgenemisega, mille tagajärjel vereringe aeglustub ja seetõttu tõepoolest muutuvad jäsemed 
jahedaks. Uskumustes peegeldub see, mida meditsiin on hiljem kinnitanud. Mõningate haiguste puhul võis saartel ka jalgade paistetus surma ennustada. Kui haige üle pea vaatas, oli see surma tunnuseks. Ka liivlastel ennustas see surma (Loorits 1932b: 178). Setumaal usuti, et enne surma muutuvad sõrmeotsad kõveraks.

Haige vaade tundus surma eel eriliselt võõrana - silmad olevat kui klaasist ja auku jäänud. Võrumaal öeldakse: Silmä omma hauda sadanu.

Üle-eestiline uskumus tänapäevani on, et kui raskesti haige muutub rahutuks, ei püsi enam voodis, vaid käib majapidamist üle vaatamas, on oodata tema surma. Haige välise oleku muutus väljendub surma läheduse tunnetuses. Pikalt põdejal tekib mõnikord enne kriisi eufooriaseisund, räägivad meditsiinitöötajad tänapäeval (TK 1995, $13<$ Rakvere).

Üks haige vanainimene muutus jörsku kõbusaks. Virgalt hakkas ta oma kodu korda seadma. Töö edenes hästi. Nagu mingi sisemine jõud aitas teda. Jõudis oma tööga lõpule ja hommikul heitis hinge. [---] Inimene tunneb kõike ette. Ainult ta ei tea, mis on just tulemas. See on mingi sisemine hääl või tundmus... keegi ei tea, mida tunneb inimene, kes hakkab siit ilmast lahkuma. Tavaliselt loodetakse tervenemisele ja elu jätkule (TK 1990, 1 < Viru-Jaagupi khk).

Kui haige keeras näo seina poole või kui ta hakkas rääkima pikkadest teedest ja kõndimisest, arvati sel olevat läheneva surma tähendus. Pikk tee sümboliseerib teed surnute riiki. Ka tänapäeval usutakse, et teest rääkimisel on surma tähendus (TK 1990, 1-4 < Rakvere).

Lõuna-Eestis täheldati, et enne surma jäävat inimene jõuetuks ja uniseks või muutuvat tigedaks. Ka tänapäevased elulised tähelepanekud viitavad sellele:

Raskesti haige ei soovi, et teda kogu aeg tülitatakse ja päritakse. Jõuetuks teeb aga pikaajaline haigus kindlasti (TK 1995, $13<$ Viru-Jaagupi khk).

Vahetult enne surma olevat haigele iseloomulik eriline hingetõmme (viimane hingetõmme), mille puhul nii pea kui ka keha liiguvad. Kui haige kellelegi, kes teda vaatamas käis, meelde jäi, ennus- 


\section{Tiia Ristolainen}

tas see tema surma. Antud uskumus on levinud ka tänapäeval (TK $1998,1<$ Tartu). Haige näol eristatakse nn surmajumet, mis peatset surma ennustavat. See on tänapäeval taas aktuaalne uskumus, väidavad meditsiinitöötajad (TK 1995, 13 < Rakvere). Enne surma pidi haige ninaots teravaks muutuma, üles kaarduma või hakkab haige nina torkima. Veel on täheldatud, et keel jääb kangeks ja huuled muutuvad siniseks või tuleb vaht suule, kõrvad hakkavad peast eemale hoiduma, muutuvad siniseks nagu ninagi või kaob kõrvakuulmine hoopis. Haige ninaotsa teravaks muutumise järgi ennustasid surma ka liivlased (Loorits 1932b: 178). Tegemist on konkreetsete tähelepanekutega enne kellegi surma. Surma tunnuseks on peetud ka surmavilli, surmahigi (külma higi) otsaette tulemist. Lõuna-Eestis öeldi: Soe higi annab elulootust, külm viib hau$d a$. Ida-Virumaal ennustasid surma ka surmaplekid naha all - erilised tumedad laigud.

\section{Haige soovid}

Üheks kõige levinumaks surma tunnuseks peetakse seda, kui haige pole millegipärast rahul oma voodiga, vaid tahab teist aset. Ka 1990. aastatel usuti seda ennet (TK 1990, 10 < Viru-Jaagupi khk). Soome ja liivi rahvausundites on tuntud analoogilised tähelepanekud (Vilkuna 1959: 65; Loorits 1932b: 179).

Mäletan, et päev enne ema surma käis ta rahutult toast tuppa ja heitis kord diivanile, siis jälle voodisse - kuskil ei olnud hea (TK 1999, $1<$ Tartu).

Mõned haiged tahavad enne surma õues käia, et seal nagu viimast korda kõik üle vaadata ja meelde jätta ning veenduda, et kõik on korras. See on sümboolne hüvastijätt, mis on tuttav ka liivlastele (Loorits 1932b: 179). Ühe informandi sõnul oli ta sugulasel väga raske paar aastat tagasi haiglavoodis elust lahkuda, sest ta ei olnud surmaks ette valmistunud, vaid tulnud mõneks ajaks haiglasse abi saama. Kõik tööd ja tegemised jäid pooleli, korraldamata, hüvasti jätmata (TK 1996, $10<$ Tartu).

Külaühiskonnas oli kombeks kutsuda omaksed ja sugulased enne surma haige juurde, et ta näeks neid viimast korda ja saaks hüvasti jätta. See nn viimane külaskäik on ka nt liivlastel tuntud (Loorits 1932b, 179). Teel surija juurde pandi tähele märke: kui juhtus keegi vastu tulema või üle tee minema, kas jänes, hunt, rebane, en- 
nustas see haigele surma. Sama enne on ka leinarongile vastutulekuga seotud. Ilmselt on siin tähtis motiiv üle tee minemine, mis tähendab tee (analoogia alusel elutee) äralõikamist.

Kui surija mõnda teatud sööki saada tahtis, olevat surm ligidal. Söökidest on loetletud: jõhvikad, hapupiim, mesi, värske kala, hapu leem jne. Haige suus tunduvat need toidud mõrud. Samad tähelepanekud on ka liivlastel (Loorits 1932b: 36). Ka 1990. aastatest leidub teateid, et surija soovib mingit erilist toitu, midagi head, näiteks mustikakisselli (TK 1996, $10<$ Tartu). Lihatoite hakkavat haige enne surma vihkama, usuti Põlvamaal. Keda haige enne surma viimasena näha tahab või hõikab, see surevat järgmisena. Kui haige surma eel veel oma lemmiklooma nimetas, arvati ka see peagi surevat. Tänapäeval täiendatakse, kui haige inimene ei tunne oma lähedasi või hakkab raske haiguse ajal tulevikuplaane tegema, on see surmaenne (TK 3, $2001<$ Ida-Virumaa).

\section{Kirikliku taustaga ended}

On usutud, et ka jumalasõna võib otsustada, kas haige on surija või mitte. Raskesti haigele lasti kirikus hingepalvet teha. Kirikliku eestpalve ajal jälgiti haige käitumist ja ennustati selle järgi ta edasist saatust (Hupel 1777: 97). Haige pidi sel ajal, kui ta eest paluti, ärkvel olema ja jumalaarmu vastu võtma. Kui ta magama jäi, tähendas see surma. Kui laps ristimise ajal magama jäi, tähendas see temagi peatset surma (Forselius \& Boecler 1914: 13). Magamise seisund sarnaneb rahvausundi järgi surmaseisundiga. Samas võib siin tegemist olla ka kirikupoolse manitsusega: kirik ja palved on pühad, neid tuleb hoolikalt jälgida ja neist kinni pidada, muidu võidakse inimest isegi surmaga karistada. Samas on tähelepanuväärne, et jumala peale surija päästmise mõttes ei loodetagi. Tahetakse ainult haige kohta tehtud otsust teada saada. Kirikliku eestpalve ajal jälgiti ka kogudust. Kui sel ajal häälitseti või köhiti, pidi haige ellu jääma, kui aga kirik oli vaikne kui haud (analoogia!), pidi haige surema. Sisuliselt pole siin tegemist jumala palumisega, vaid rituaali täitmisega, kus on segunenud nii kristluse kui ka animistliku surnutekultuse elemendid.

August Wilhelm Hupeli järgi peeti kirikuõpetajat ennast parimaks ettekuulutajaks (Hupel 1777: 67). Vaadati, kuhupoole küünlaleek kandub, kui õpetaja toast lahkub: kui ukse poole, siis läheb sinnapoole ka haige, jalad ees (Wiedemann 1876: 461). Johann Wolfgang Boecler räägib haige saatuse ennustamisest kirikuõpeta- 


\section{Tiia Ristolainen}

ja hobuse abil: kui hobune õpetaja õue sõites pea norgu laseb, haige sureb (Boecler 1854: 67). Seda uskumust mainib ka F. J. Wiedemann (Wiedemann 1876: 461). Sama enne on rahvapäraselt tuntud üle Eesti. Kui pärast kirikuõpetaja lahkumist lendasid üle õue mustad linnud, ennustas see haige surma.

Ei saa öelda, et ametlik usk neis uskumustes olulist osa mängiks. Pigem on ta segunenud rahvapäraste uskumuste ja ettekujutustega. Veikko Anttoneni järgi moodustavadki rahvapärane ja kiriklik teineteisega põimunud kultuuriterviku. Kristliku traditsiooni mõju rahvapärasele kultuurile tuleb vaieldamatult esile suulises rahvapärimuses. Ka pole kristlus puhas rahvapärase ja paganliku mõjudest (Anttonen 1992: 2516). Kuni haige surmani on kombestikus ülekaalus analoogiamaagia, püütakse teada saada, mis tuleb. Surma ärahoidmine ei ole eesmärk.

Psühholoogiliselt on raske üle elada kokkupuuteid surmaga assotsieeruvate sümbolitega, kui keegi lähedastest võitleb haigusega elu ja surma piiril. Ühe informandi sõnul vihastas ta, kui nägi linnatänaval elegantset musta kübara ja looriga üsna väljakutsuvalt tumedasse riietatud daami, sest õde võitles parajasti haiglas surmaga. Nähtu tundus surmaendena. Pärast õe surma samas riietuses naist nähes ei ärritunud ta enam (TK 2000, $2<$ Tartu). Lähedasi ajavad ka teiste inimeste pessimistlikud tõlgendused haige suhtes vihale. Kardetakse, et surmatunnustest juba ette rääkides kutsutaksegi surm esile.

\section{Surnuga seotud surmaended}

Surnu kehas valitsevate vaenulike jõudude tegevuse edasiseks teadasaamiseks jälgiti hoolega laipa. Normist kõrvalekaldumine midagi ebatavalist - ennustas uut surma. Laibaga seotud surmaendeid on suhteliselt palju. 19. sajandil olid need veel ilmselt üsna aktuaalsed (enamik M. J. Eiseni ja J. Hurda kogudes, 19. sajandi kirjapanekutes). 20. sajandil oli enamik neist oma aktuaalsuse kaotanud, kuigi üksikuid usuti veel 1990. aastatelgi.

\section{Surnu vaatlemine}

Elust lahkumise momendil jälgiti hoolikalt surija silmi. Kuhupoole ta viimasena vaatas, sealt pidi järgmine inimene surema, usuti Se- 
tumaal. Kui surnu silmad lahti jäetakse, pidi majast keegi surema. Ilmselt seletati seda analoogiaga: kui silmad lahti jäid, võis tunduda, et surnu vaatab kellelegi otsa ja kutsub ta kaasa. Just Knud Qvigstadi järgi tunnevad sellist uskumust ka laplased (Qvigstad 1920: 55).

Surnu suust kardeti surmahaiguse väljatulemist ja teiste nakatamist. Seetõttu suleti ka surnu suu. Kui see kinni ei jäänud, ennustati taas järgmist surma. Mõnikord ei olnud laiba nägu kahvatukollane, vaid säilis punakas jume. Ka see ennustas uut surmajuhtumit. Kui surnu nägu osutus palpeerimisel pehmeks, pidi samast perest peatselt uut surnut välja kanda saama (Wiedemann 1876: 461-462).

Arhiivimaterjali hulgas on suhteliselt vähe endeid, mille puhul ennustatakse järgmise surnu sugu. Rahvapäraselt on mõistega vasak seotud naine ja paremaga mees. Seega võrreldi laibal paremat ja vasakut poolt, et ennustada, kummast soost on järgmine surnu. Vaadeldi ka surnu jäsemeid. Kui need olid soojad või pehmed, võis samast perest uut surnut oodata. Võrreldi ka surnu jalgade pikkust - kui üks oli pikem, ennustas see peatset surnut samast majast. Vasaku ja parema jala võrdlemisel otsustataksegi üle Eesti, kas tuleb nais- või meessurnu. Vaatlusobjektiks olid ka surnu käed. Kui käed või küünealused tõmbusid valgeks, mitte siniseks, pidi keegi talust surema, usuti Setumaal. Kui surnu käed tundusid puudutusel pehmed või soojad, ennustas see samast majast või suguvõsast surma. Ka siin võrreldi kohati vasakut ja paremat kätt, et tulevase surnu sugu kindlaks määrata. Kui surnu sõrmed kramplikult kokku tõmbusid, pidi ta kellegi kaasa viima.

Läänemaal usuti, et kui surnu suur varvas pikemaks venib, on võimalik uus surmajuhtum. Kui surnu tõstmisel tundus, et keha on veel soe, ennustas see omaste surma. Üle-eestiliseks surmaendeks on see, kui surnukeha ei kangestu. Kui surnukeha on nõrk, ennustab see ka tänapäeval Setumaal uusi surnuid (Arpo 1996: 254255). Laiba kangestumise järgi ennustavad surma laplased (Qvigstad 1920: 55).

\section{Tähelepanekud matustel}

Veel matuste ajal võis laip ümbritsevat mõjutada. Surnut saadeti toast välja põleva küünla saatel ja vaadati seejuures, kuhupoole küünalde suits läheb. Kui toa poole, pidi majast veel keegi surema. Kui see hoopis kustus, ennustati surmajuhtumit suguvõsasse. Selle järgi, kes esimesena surnu asemest möödus või selle kohale as- 


\section{Tiia Ristolainen}

tus, ennustati majja uut surnut vastavalt kas meeste või naiste hulgast.

Suririiete õmblemisel ega puusärgi tegemisel ei tohtinud materjali alles jääda. Tegemist on uskumusega, mille järgi surnu valmistab järglast vastu võtma. Kui surnusärki õmmeldes lõng sõlme läks, ennustas seegi uut surma (Wiedemann 1876: 461-462). Kui surnukirst pärast surnu kirstupanekut nagisema hakkas, pidi surm uuesti majja tulema, usuti Põltsamaal. Kui kirstupanekul selgus, et surnu kirstu ei mahugi, pidi veel keegi surema. Siinjuures toimib lihtne analoogia: kirst ootas sobivat surnut. Ka liiga suur puusärk ennustas uusi surnuid. Hoolega jälgiti, et oma veri matmise ajal hauda kaasa ei läheks, ka puusärgi tegija pidi ettevaatlik olema. Kui end kogemata vigastati, ennustati iseenda või lähedaste surma. Matustega ei tohtinud viivitada, muidu pidi surmavaim liiga kauaks koju jääma. Tänapäeval usutakse, et kui surnu jääb pühapäevaks koju, läheb keegi talle järele (EFA I 69, 16 < Ida-Virumaa, Lüganuse khk - Selma Vasar (2001)).

Kõiki surnuga kokkupuutunud esemeid kardeti. Kuna surnuraam puutus surnuga vahetult kokku, pidavat see iseenesest lähedal seisjat lööma ja teatama sellega, kes on järgmine surnu. Kui naine surnuraamile toetas, määras ta kõik oma järeltulijad surmale, usuti Raplamaal. Kui raam koju toodi, ei tohtinud seda asetada nii, et jalad jäid ülespidi - ennustas uusi surnuid. Setudel viiakse surma tõrjeks koguni raam metsa. Oli vaja katkestada kontakt surnuga. Ka sõidukit, millega surnut viidi, ei tohtinud Lõuna-Eestis kohe majja tagasi tuua, sest sellel oli aktiivne surmatoov mõju. Naine ei tohtinud seetõttu surnuvankril istuda, muidu oleks ta sellega kõik oma lapsed surnuaeda sõidutanud. Samal põhjusel ei tohtinud vanemad oma last matma minnes tema kirstu kõrvale istuda - teised lapsed oleksid surnud. Lõuna-Eestis oli keelatud lapse vanematel oma surnud last kalmistule saata, et mitte kutsuda õnnetust teistele lastele kaela. Ohtlik on ka surnud lapse tõstmine ja kandmine.

Antud tabudel ei ole tegemist aktiivse ennustamise vormidega. Tegelikult kujutavad need keelud endast tõrjemaagiat. Objekt on olnud otseselt kontaktis surnuga, millest oli vaja kiiresti ja lõplikult vabaneda, ta pole lihtsalt mis tahes kujuteldav üleloomuliku jõuga ese või nähtus.

Üldise uskumuse kohaselt pidi surnukirstu majast välja viies hoolega jälgima, et see midagi ei riivaks, muidu märgib surnu ära, 
et ta tahab enesega veel kedagi kaasa võtta. Sama uskumus kehtis ka surnuristi majast väljaviimisel. Asjadest, mis kuulusid kirstu või surnuvankri juurde, ei tohtinud midagi maha kukkuda. Eriti halb märk oli, kui surnu ise kandjate käest maha kukub. Arvestades eestlaste esivanematekultust, oleks see olnud tõeline eksimus. Lisaks seostatakse rahvausundis mitmesuguseid mahakukkumisi surmaennetega.

Matustele minnes jälgiti, kes läheb esimesena leinamajast puusärgi järel välja - kui mees, pidi surema meessoost inimene, kui naine, siis naissoost. Surnukirstu järel kõndides komistaja või kukkuja oli järgmisena surmalaps. Sama seostati kirstukandjatega. Öeldi, et komistajal kõnnib surm vikatiga järel. Hiiumaal ennustas uut surmajuhtumit seegi, kui kirstukandjad üle õla tagasi vaatasid. Setumaal ennustas surmajuhtumit vasaku jalaga esimese sammu astumine. Ilmselt on siin rahvapärane seos personifitseeritud surmakujutelmaga. Rahvausundi järgi juhtis Surm käimist ja andis endast sellisel viisil märku (Loorits 1949: 81; Loorits 1927: 4).

Surnut kodust välja saates lauldi. Kui lauluhääl iseloomulikult selgelt ja kaugele kostis, ennustati, et majast sureb veel keegi või sureb sealtpoolt, kuhu hääl paremini kostis. Selle järgi on ennustanud ka vadjalased (Ariste 1969: 83) ja liivlased (Loorits 1927: 10). Kui lehm surnu majast väljaviimise ajal ammus, pidi veel keegi surema, samuti nagu koerte ulgumise või haukumise korral, sest loomad tundvat pererahva surma ette (vt lähemalt Loomadega seotud surmaended).

Üldise uskumuse kohaselt ei tohtinud matmise päeval midagi koju unustada, see ennustas uut surnut. Sama enne ka liivlastel (Loorits 1932c: 196). Antud uskumust teatakse tänapäevalgi.

Mis surnule on määratud, ei tohi koju jätta (kü̈̈nlad, lindid), muidu viib endaga kaasa (EFA I 69, 16 < Ida-Virumaa, Lüganuse khk - Selma Vasar (2001)

Surm ähvardab ka neid, kes kalmistule midagi maha unustavad. Suurim patt oli risti koju unustamine, mis tähendas pereliikme surma. Surma tähendas ka see, kui rist hauale panemata unustati. Verb unustama on läänemeresoomlastel tuletatud sõnast uni. Unustamine tähendas niisiis algselt unes olema - see tähendab inimese viibimist seisundis, kus hing kehast lahkub. Magamise ja surma seisundit on rahvausundis identifitseeritud (Loorits 1949: 275), ai- 


\section{Tiia Ristolainen}

nult selle vahega, et ühel juhul hing pöördub kehasse tagasi, teisel juhul mitte.

Kalmistule sõideti ettevaatlikult kõikidest reeglitest kinni pidades, muidu ennustas see uut surnut. Kui teel midagi katki läks (look, vanker, ratas vms), oli see uue surma enne. Tõrjemaagias aitas selle vastu ristikese tegemine sinna kohta.

Leinarongis jälgiti ka teisi matuselisi. Kui keegi vaatas surnuga väravast välja sõites tagasi, ennustati (eriti saartel) sellesse peresse surma. Saaremaal arvati, et sureb see, kes tagasi vaatab. Selle uskumuse järgi on ennustatud ka järgmise surija sugu: kui tagasi vaatab mees, sureb järgmisena meessoost inimene, kui naine, on järgmine surija naissoost. Matuseliste tagasivaatamist on seostatud mõttega, et sellega võisid nad surma koju jätta. Üldine on uskumus, et matuselistele esimese vastutulija soo järgi ennustatakse järgmist surnut. Vaadati ka, kas pärast surnu äraviimist tuleb esimesena väravast sisse mees või naine. Seegi ennustas analoogia alusel mehe või naise surma. Kellele leinarong vastu tuli, see oli määratud surema. Mida kaugemal kodunt tuli keegi vastu, seda pikema aja jooksul polnud surma karta - ennustamine analoogia põhjal.

Eesti kiviaedadega piiratud külavaheteed olid tihti umbes, seetõttu sõideti teiste õuede kaudu, kuid matuste puhul oli see keelatud. Ei tohtinud surmavaimu teistele viia. Kui kuskil peatuti, ennustas see sealt uut surnut. Seda uskumust kirjeldab ka Jaan Jung (Jung 1879: 113).

Hoolikalt tuli jälgida, et labidas, millega hauda kaevati, või tekk, mis oli kirstul olnud surnuaeda sõidul, ei satuks teiste perede vankrisse - viiks surma neile. Samalaadne on ka uskumus, et leinamajast või surnuaialt ei või külaleiba kaasa tuua, muidu tuuakse ka surmavaim kaasa. Surnuaialt kaasavõtmise keeld võib olla seotud ka eetiliste kaalutlustega. Teisest küljest püüti hoiduda igasugustest kontaktidest surnuga. Ka tänapäeval usutakse, et surnuga seotud kohtadest ei tohi midagi kaasa võtta. Nii ei tohi surnuaiast lilli noppida ega varastada. Hoiatav näide selle kohta on Lõuna-Eestist (TK 1990, 12 < Tartu, Lääne-Virumaa) - lillede võtmine surnuaialt lõppes autoavariiga, kus varastaja surma sai.

Ka uut perenaist ei toodud sama teed mööda tallu, kust surnu välja viidi. Seega püütakse surma majast eemal hoida surnuga vahetu kontakti vältimise teel.

Matma minnes vaadati, kust tuul puhub. Kui tuul oli vastu, tähendas see üldiselt, et majast keegi sureb - tuul toob surma koju 


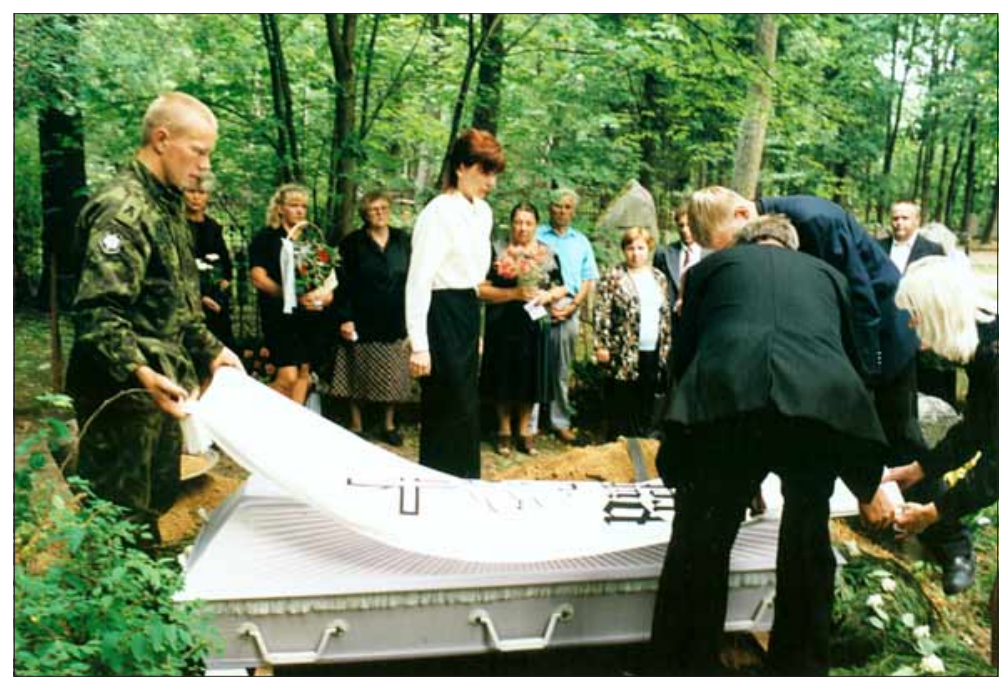

Foto 5. Matustel ei tohi ühegi tava vastu eksida. See käib ka surnukirstu lina või tekiga katmise kohta (pildil). 1999. Foto erakogust.

tagasi. On usutud ka vastupidist - tuul puhub õnne tagasi. Palju ennustusi on seotud surnu hauaga. Kui see enne surnu haudalaskmist varises, ennustati uusi surnuid. Üldlevinud eetiline nõue on, et matuserongi möödumisel peab töö seisma jätma, muidu toob see õnnetust. Tänapäeval kohati arvestatakse sellega - seisatatakse töö, jäädakse seisma (või jäetakse auto seisma), kuni matuselised mööduvad, ja võetakse peakate peast. Samas kurdavad aga informandid, et inimesed kipuvad kiiruse tõttu seda kommet unustama.

Pärnumaal ennustati, et esimesena pidi matuselistest surema see, kes surnut viimasena vaatas. Haual komistamised ja kukkumised ennustasid surmajuhtumit igal juhul. Kui matmise ajal kääbas täis ei saanud või haud pärast matuseid vajus, ennustati, et keegi lähedastest tuleb peagi järele - surnu jättis enese kõrvale hauda ruumi teistele. Matuserituaalide sooritamisega ei tohtinud eksida, see oli halb märk tulevikuks. Ilmselt seostatakse laulusõnade või palve segaminiajamist eksitajaga, kelleks võis olla personifitseeritud surm.

Kes viimasena surnuaiale jäi, sellele või ta suguseltsile ennustati järgmist surnut. Liivlased ennustasid just vastupidi: kui kalmistult 
Tiia Ristolainen

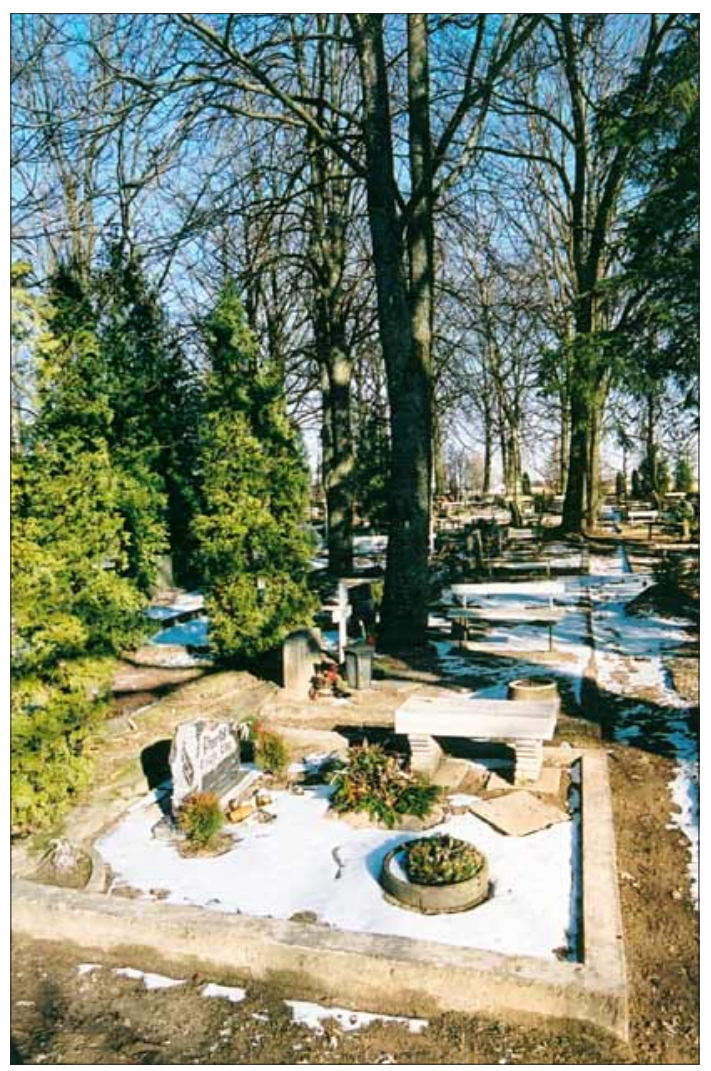

Foto 6. Surnuaialt ei tohi midagi kaasa võttaarvatakse, et see toob onnetust. Andres Tennuse foto 2002.

lahkus esimesena mees, pidi järgmine olema meessurnu, naise lahkumise korral - naine (Loorits 1932b: 197). Peielaua puhul jälgiti, et kui laua katmisel nõud maha kukuvad, tähendab see surma. Saaremaal ennustatakse järgmist surnut esimese söömahakkaja järgi. Jüris arvati, kes viimase matusteviina joob, see esimesena sureb.

Selle rühma ennustustes on rohkesti keelde ja hoiatusi, mille põhjusteks on ühest küljest hirm tulevase surma ees ning teisest küljest soov lähedasi eksimusteta matta. Inimese elu pöördepunktidel tajutakse elu oluliselt laiemas plaanis. 
Tiia Ristolainen

\section{0. Üksikteated}

Arhiivis leidub hulgaliselt üksikteateid, mida võib käsitleda uskumustena: külainimese tulek kanga lõpetamisel; kuuseokka maitse söögil, üksinda surnuaiale minek, silmade pühkimine saunast tulles, pudeli ümberkukkumine laua peal ja selle katkiminek, kellelegi eriline silmatorkavus, kohvitassi kummuli lauale panemine, leiva keskelt pakatamine, raamatu avatuna lauale jätmine. Meremehed on väitnud, et kui suured kalad laeva ümber tulevad, ennustab see surma. Nina sügelemine tähendab surmasõnumeid - tänapäevalgi usutakse seda Virumaal. Täpsustatakse, et kui nina on külm, tähendab see surmasõnumeid, kui soe - titeuudiseid (TK 1996, 3 < Rakvere). Töö ja materjali üheaegne lõppemine võis ennustada surmajuhtumit analoogia alusel. Kui rätsepal niit töö lõpul otsa lõppes, olevat ette kuulutatud, et neid pükse lõpuni ei kanta - seega ennustati pükste omaniku surma. Nõela murdumine oli analoogne elutee katkemisega. Surmaenneteks loeti ka seda, kui lapsed tihti surma mängivad, kui enne matustele minekut kodus leiba tehti ja see labidalt maha kukkus, kui põlevale küünlale midagi laastu või naela sarnast külge ilmub. Mitmesugused külgejäämise motiivid on eesti surmaennetes laiemaltki tuntud: kui kellelgi õlekõrred riiete küljes ripuvad, tähendab see surmasõnumite saamist.

Eesti vanausulistel on uskumus, et peegli lõhkumine tähendab surma.

Rahvapärane seletus on, et peegel kannab inimese energiat, seega kui peegel puruneb, kaotab inimene oma elujõulisust. Selleks, et onnetust vältida, tuleb viivitamatult kõik killud märja luuaga kokku koguda ja koos luuaga kodunt kaugemale ära visata. Kätega ei tohi puutuda (Richter 1976).

Tänapäeval on omistatud toalille kuivamisele surma ennustav tähendus - analoogia inimese hääbumisega (TK 1998, 1 < Tartu, Tapa).

Eespool toodud ennustused on üksikud, neid esitatakse ainult seoses konkreetsete surmajuhtumitega, seega on need saanud oma tähenduse post factum. Üksikuskumuste puhul võib väita, et tegemist on rahvausundi äärealadega, unustamisstaadiumiga või vähelevinud laenudega, sest samasisulisi endeid leidub ka teistel rahvastel. Näiteks kui jalg kogemata ukse vahele jääb, ennustab see surma ka laplastel (Qvigstad 1920: 52). Liivlastel ennustab parema jala ukse vahele jäämine mehe surmast kuulmist (Loorits 1932c: 173). 


\section{Tiia Ristolainen}

Suhteliselt nõrgalt on surmaennetes esindatud tõrjemaagia. See sisaldub õpetustes ja hoiatustes: ära pane pingi jalgu üles, ema sureb ära; ära käi ratta rööpais, ema või isa sureb! Hoiatati, et kes lund sööb, sureb noorelt. Ilmselt olid hoiatused mõeldud laste korralekutsumiseks ja hirmutamiseks, mis võib juhtuda keelust üleastumisel. Tänapäeval on need kadunud.

\section{Aktiivne ennustamine}

Paljud aktiivse ennustamise viisid pärinevad ammustest aegadest, mil arstiabi puudus või oli vähene. Ennustamine toimus iseendale ja haigele inimesele eesmärgiga teada saada, kas ta jääb elama või sureb. Eesti Rahvaluule Arhiivi teadete järgi viitab enamik ennustuste tulemusi surmale, vaid üksikud annavad paranemislootust. Kui osa passiivsetest ehk vaatlusel põhinevatest surmaennustustest on tänapäeval veel aktuaalsed, siis aktiivsed surmaennustused on taandunud. Ilmselt on üheks põhjuseks nende aktuaalsuse kadumine, samuti arstiteaduse areng.

Tänapäeva inimesele on oluline iga hinna eest elu pikendada, mitte surmale mõelda. Surmaennustustes võib ära tunda vanu ohvrikombeid. Looduslähedane inimene uskus, et loomad teavad ja tunnevad rohkem kui inimene ise, sest neile antakse rohkem teada. Usuti soola imettegevat mõju, tule ja vee puhastavat toimet jne. Ennustusvahenditena tervele inimesele on kasutatud nt surnuga seotud esemeid: õled, surnupesuvesi, surnuraam jm. Surmaennustamise peamised vahendid olid vesi, taimed, pirrutuli, viht, õled, lauluraamat, surnupesuvesi.

\section{Vesi}

Vesi oli universaalne ennustamisvahend, mille abil võis teada saada nii head kui ka halba. Haige elu pikkuse ennustamisel loodi lihtsa analoogiaga assotsiatsioon: kui kaevust võetud vesi panges päripäeva ringi käib, haige paraneb, kui vastupäeva - haige sureb. Seda analoogiamaagiat laiendati ka arstide tööle: vaadati, kuidas rohi klaasis liigub. Üks vanemaid maagilisi võtteid - elavate süte vette asetamine ning vee ringlemise jälgimine - on olnud kasutusel järgmiselt: kui söed püsivad vee peal, jääb haige ellu, kui põhja vajuvad, sureb ka haige. Viljandimaalt on teade, et ennustamisel on kasutatud süte asemel peeneid nõelu. 
Tiia Ristolainen

\section{Sool}

Sool on eestlastele nagu muudelegi rahvastele olnud imettegev vahend, mis aitab säilitada ega lase lihal hapuks minna. Ennustamiseks võeti haiget vaatama minnes soola pihku - selle sulamine tähendas haige surma. Samuti tehti surnu valvamise juures, soola sulamine tähendas, et veel samal aastal oli uut surnut oodata. Eestlased on ka vana-aastaõhtul soola abil ennustanud: igaühele pandi laua peale nimelise tassi alla veidi soola - kelle oma hommikuks ära sulas, see pidi järgmisel aastal surema. Sama komme on tuntud ka soomlastel (Varonen 1892: 167). Sealses traditsioonis pandi ka pühakutepäeva õhtul igaühele peres aknale soola. Ennustamine toimus jällegi sulamise järgi (Varonen 1892: 167). Igasuguste loomaõnnetuste vastu anti ja antakse ka tänapäeval uusaastaööl loomadele soola (TK II, 13 < Lääne-Virumaa). Soola üleloomulikku jõudu on tunnustanud paljud rahvad. Nii pannakse vana läänegooti, inglise ja sorbi kombe järgi soola laibale või visatakse hauda. See on nii surma tagasituleku takistamiseks kui ka halbade vaimude eemalehoidmiseks surnust (Ranke 1951: 172).

\section{Loomad}

Rahvapärimuse järgi tunnevad loomad inimese surma ette, seetõttu on neid kasutatud surma ennustamisel. Näiteks elusa konna asetamisel haige rinnale tähendas sinna vaikselt püsima jääv või surev loom sama ka haigele. Rahvausundis on see seletatav hingekujutelma abil - kui hingejõud on nõrk või otsas, ei peleta ta isegi väikesi loomi eemale, mis annab tunnistust peatselt saabuvast surmast.

Koer on läheneva surma suhtes olnud ilmselt targim koduloom, sest tal on vahetu kokkupuude oma perega. Kihnus on pekitükki hõorrutud haige jalataldade vastu ja pakutud siis koerale. Kui ta seda ei puutu, on see märk inimese suremisest, nagu söömine tervenemisest. On teada veel teinegi koeraga seotud ennustusviis, ülekirjutus pärineb Harjumaalt, kus raskesti haige inimese suupesuvesi visati koerale selga. Kui koer selle maha raputas, tähendas see haigele surma. Hiiumaal on võetud leivatükk või kartul, pandud lauatükikese peale ja pakutud seda esimesele vastutulevale koerale (varem ka hundile). Kui see toidu inimese käest ära tõmbas, pidi haige terveks saama, kui ei, siis polnud lootust.

Surmaennetes on kassilgi kindel koht. Kassivihkajate surm pidi olema tunduvalt raskem kui teistel inimestel. Jõgevamaalt pärit tea- 


\section{Tiia Ristolainen}

tel pandi haige voodisse kass - kui ta sinna magama jäi, pidi inimene tervenema. Haige kartmine ja maharonimine tähendas surma.

\section{Taimed}

Ennustati rukkipea - leiva sümboli - abil. Kui majas oli keegi haige, pandi küpsetatava leiva sisse rukkipea. Kui see ahjus ära kõrbes, ootas haiget surm. Otepäält on selle ennustusviisi kohta Jakob Hurda ja Matthias Johann Eiseni kogudes mitmeid teateid, mis viitab 19. sajandil levinud uskumusele (hilisemad teated puuduvad, muutus ka leivategemise viis). Rukkipeaga ennustamisest soomlastel kirjutab Matti Varonen (Varonen 1892: 167).

Metsikutest taimedest on Saaremaal ja Kihnus kasutatud nõgest. Haigel lasti nõgeste peale urineerida. Kui need ööpäeva jooksul mustaks ei tõmbunud, pidi haige elama jääma. Seda võib seletada uskumusega, et surm (kurjad jõud) arvatakse olevat haige sees. Kui nad võitluses haigega on ülekaalus, võivad tema eritiste kaudu tappa ka elava looduse, millega ta kokku puutub (vrd konn sureb haige rinnal).

\section{Pirrutuli}

Pirrutule kohta arvati Lääne-Virumaal ja Lõuna-Eestis, et see toob esile erilised varjud haige ümber, kui see surema hakkab.

\section{Viht}

Viht oli ennustamisel olulisemaid vahendeid. Järvamaal visati see katuseräästa all üles. Kui ta kukkus alla, latv ees, pidi haige surema, kui tüvi ees, arvati elama jäävat. Analoogset ennustamist kasutasid vadjalased jaanipäevakombestikus (Ariste 1969: 85, 89, 92, 94).

\section{Lauluraamat}

Analoogiamaagia abil ennustati nt Lääne-Virumaal lauluraamatu abil surma. See löödi lahti ja kui parema käe pöidla alla jäi salm, mis rääkis surmast, oli oodata seda ka haigele.

Nii surnu kui ka surnuga vahetult kokkupuutunud esemed tähendasid tervele inimesele alati surma, millega ongi seletatavad tõrjemaagia mitmesugused rakendusviisid puuteobjektide suhtes. Maagia sellised vormid tingis usk, et surm tuleb omal ajal ja omas kohas. Kindlaim võimalus pikaks elueaks oli sellistest asjadest eemale hoid- 
mine. Osa ennustamisi toimus surnuga kontaktis olnud esemete abil, millest 19. sajandil olid olulisemad õled, surnupesuvesi jms esemed.

\section{Õled}

Haige tõsteti õlgedele ja neist sai oluline ennustus- ja tõrjevahend. Õled pandi hauda kirstu alla. Lautsiõled asetati Setu-ja Pärnumaal kindlale kohale teele maha, vaadati, kes neist esimesena üle astub, see pidi järgmisena surema. Suur osa teadetest räägib, et õled põletati ära hoidmaks surma talust eemal. Sama komme on tuntud ka laplastel (Varonen 1892: 91) jt rahvastel. Setumaal hüppasid matuselised üle surnuõlgedest tehtud tule. Sinna visati ka mõne vana savipotiga surnupesuvesi. Pott pidi purunema ja kui seda ei juhtunud, löödi katki ja vaadati selle jälge tuhas. Kui tekkis suur jälg, suri järgmisena suur inimene, kui väike, siis analoogia alusel väike. Tuha pealt ennustamine on tuntud ka teistes kihelkondades. Uusaastaööl siluti koldes tuhk ja vaadati, kui hommikul oli seal inimese jälg, suri sel aastal majast keegi (Wiedemann 1876: 461; Forselius \& Boecler 1914: 25). Sama komme tuntud ka soomlastel (Vilkuna 1959: 67).

\section{Surnupesuvesi}

Surnupesuvesi kallati kõrvalisse aianurka, et keegi sellega kokku ei puutuks, muidu ennustaks see surma. Arvati, et alati sureb kolm inimest järjest, mille teadasaamiseks visati nt Pärnu ja Ida-Virumaal surnupesuvesi vastu õunapuud või vahtrat ja kuulatati. Kust müdinat, kobinat või vingumist kuuldi, sealtpoolt oli järgmine surnu. Hääle suund märgib rahvausundis ikka surmapaika.

Dualistlik arusaam headest ja kurjadest jõududest ei ole eesti usundis küll võtnud äärmuslikke vorme, kuid kahtlemata võime leida selle jälgi kas või elu ja surma polarisatsioonis. On loomulik, et sellise nähtuse nagu surma puhul püüti abivahendeid kasutades tema liikumisest ülevaadet saada. Eelnevast selgub, et sihipärase ennustamise vorme on olnud suhteliselt vähe. Samas on aga kogutud vastavasisulisi teateid üle maa, mis lubab oletada, et tegemist on vanade ennustamisviisidega, mida tunti laialdaselt. 20. sajandiks kaotasid need oma aktuaalsuse. Sellele on kaasa aidanud teaduse, eriti meditsiini areng ja arstiabi kättesaadavamaks muutumine, hariduse kasv ja vabamad liikumisvõimalused. Tänapäeval otsitakse ennustajatelt ja ennustamiselt abi lootusetus olukorras: 


\section{Tiia Ristolainen}

peamiselt materiaalsete asjade (näiteks auto) või kadunud inimeste leidmiseks, sassiläinud isikliku elu puhul jne.

Käesolevas ülevaates ei ole vaadeldud ennustamisi rahvakalendri tähtpäevadel, sest nende puhul ei ennustatud spetsiaalselt surma, vaid tulevikku. Surmaended võisid ette tulla muude ennete seas.

\section{Kokkuvõtteks}

Eesti surmaennustustes esineb kaks erinevat ennustusviisi:

1) vaatlusel põhinev ehk passiivne ennustamine,

2) sihipärasel tegevusel põhinev ehk aktiivne ennustamine.

Ennustustes haigele vaadeldakse eelkõige, kas ei esine normist kõrvalekaldumisi. Ennustustes tervele inimesele domineerib püüdlus vältida surnuga kontakti, kusjuures surnu oli omastele ohtlikum kui võõrastele. Seega toimis kontakt surnuga kahel viisil:

1) surnu või surnu asjadega kokkupuutumine (füüsiline kontakt), 2) veresidemed (perekondlik side).

Eesti surmaennete puhul on tähelepandav üldine uskumus, et surm tuleb ikkagi siis, kui on saabunud selleks määratud aeg. See tingib ka eesti surmaennete funktsiooni: püütakse ette aimata, mis inimest ootab, ja alles siis, kui inimene on juba surnud, püütakse kontaktide vältimise või surnuga lepitamise abil ära hoida järgmist suremist. Kuni haige surmani on kombestikus ülekaalus analoogiamaagia, tõrjemaagia saab valdavaks pärast haige surma.

Haige oli pidevalt omaste hoole all. Arvati, et iga surmajuhtumi eel saabub märguanne ükskõik mis kujul. Konkreetselt aktualiseeruvad ended siis, kui peres on haige, mis annab erilise tähenduse risti sattunud pilbastele, lauakolinale öösel jne (Tedre 1985: 65). Jaan Jungi järgi arvati surma ja haigust, õnne ja õnnetust ilmutavat end inimesele erineval kujul (Jung 1879: 9). Vaatluse teel püüti leida märke, mis annaksid tunnistust haige saatusest. Vastust sellele otsiti elukogemustest ja usundist.

Pärimuslike uskumuste ja elukogemuslike tähelepanekute vahele selget piiri tõmmata ei saa. Mis ühele pärimus, see teisele kogemus ja vastupidi (Mikkor 2001: 119). 
Oluline on siin autori arvates inimese piirkondlik päritolu ja perepärimus. Räägitakse lapsepõlvekommetest, nähtusi mõtestatakse lahti vanemate pärimuse kaudu.

Kuna elust lahkunu võis end elavatele ilmutada ka unes, andis see põhjust arvata, et inimene jätkas oma eluteed, kuigi teisel kujul ja teises ilmas. Palju surmaennustusi seostub haige magamisega. Surmaseisundit on usundis tihti identifitseeritud magamisega. Mõlemal juhul lahkuvat hing kehast.

Surmaennustustes hõlmab valdava osa analoogiamaagia, mis võib põhineda nii sihipärasel tegevusel kui ka lihtsatel vaatlustel. Terve inimese puhul domineerib surnuga seotud surmaennetes tõrjemaagia, mis seisneb peamiselt surnuga kontakti vältimises või lühendamises. Esineb ka analoogiamaagia vorme. Surmaennetes esineb rohkem rahvapäraseid uskumusi ja vaid üksikuid ristiusuga seotud elemente (hingepalve haigele, ristimärkide jälgimine). Rahvapärase arusaama kohaselt ei surnud ülekohtune inimene enne oma pattude ülestunnistamist. Inimene otsis eelkõige igapäevaelust vastust küsimusele, kui kaua tal on määratud veel elada. Surmaga seostati aastaaegade, ilmastiku, koduloomade ja -lindude käitumist jms. Paljud ennustused on tekkinud seoses personifitseeritud surmakujutelmaga (salapärased hääled). Väikese rühma moodustavad surmaga hirmutamised, mis olid suunatud lastele eelkõige kasvatusvahendina.

Kindlasti saab eestlaste surmaennete rohkust seletada maa ajalooga, ainelise ja töise keskkonnaga, mis ei võimaldanud kerget elu. Surm ei olnud kohutav hüpe teadmatusesse, selleks tuli olla vaid valmis. Autor usub, et enamik ennetest on seotud uskumusega elu jätkumisest teispoolsuses. Elu pärast surma isegi idealiseeriti.

Eestis levinud surmaennetel on paralleele soomeugrilaste, sakslaste, slaavlaste jt rahvaste analoogsete uskumustega. Surmaended on üldiselt lühikesed memoraadid, kirjeldused üleloomulikest juhtumitest, mida rääkija ise või keegi tema lähedastest on kogenud. Need tõlgendatakse enneteks ja neist räägitakse enamasti konkreetse surmajuhtumi järgselt. Artikli autori arusaama kohaselt ei olnud külaühiskonnas ega ole ka tänapäeval üldjuhul eetiline surmaennetest enne konkreetset juhtumit rääkida. Ka rahvausundi järgi ei tohtinud surmajutte niisama rääkida - muidu võidi surm esile kutsuda.

Tänapäeval on igasugused ennustused populaarsed. Igas ajalehes ja ajakirjas on oma horoskoobinurgad, raadios ja TVs tehakse neil 


\section{Tiia Ristolainen}

teemadel telesaateid. Need horoskoobid ei ennusta otseselt surma ega haigusi. Inimesed räägivad surma teemal väga ettevaatlikult. Tänapäeval tähendab surm enamat kui lihtsalt teadmatust. Kartuse ja hirmuga suhtumine näitab, et surmaennetesse ka usutakse. Tänapäeval peetakse sobimatuks jälgida haiget, et saada teada, kas ta paraneb või mitte, kuid tähelepanekuid tehakse ikkagi. Surmaended ei ole enesekohased, usutakse, et nad ennustavad surma kellelegi teisele, tavaliselt lähedastele. Seega on surmaennete arengutendents iseendast väljapoole. Tänapäeva ratsionalistlikus maailmas on uskumustemaailm varjatum - paljut ei ole sobiv uskuda.

\section{Kommentaar}

${ }^{1}$ Käesolev kirjutis on peatükk autori 2004. aastal Tartu Ülikoolis kaitstud professor Ülo Valgu juhendamisel valminud doktoritööst Aspekte surmakultuuri muutustest Eestis, uuendatud on üksnes pärimusvõistlusele Eluring laekunud tööde viited ja täpsustatud Eesti Rahvaluule Arhiivis asuvaid näitetekste.

\section{Arhiiviallikad}

$\mathrm{E}=$ Matthias Johann Eiseni rahvaluulekogu (1880-1934) ja mõned varasemad tekstid, Eesti Rahvaluule Arhiiv.

Eesti Rahvaluule Arhiivi usundikartoteegid (märksõnad surm, matused).

EFA = Eesti folklooriarhiivi rahvaluulekogu (1996), Eesti Rahvaluule Arhiiv.

ERA = Eesti Rahvaluule Arhiivi rahvaluulekogu (1927-1944).

H = Jakob Hurda rahvaluulekogu (1860-1906), Eesti Rahvaluule Arhiiv

RKM = Eesti Teaduste Akadeemia Fr. R. Kreutzwaldi nim (Riikliku) Kirjandusmuuseumi (nüüd Eesti Kirjandusmuuseumi) rahvaluule osakonna rahvaluulekogu, Eesti Rahvaluule Arhiiv.

SKS = Suomalaisen Kirjallisuuden Seura Kansanrunouden Arkisto: usunditeated; Oskar Looritsa käsikirjalised materjalid.

TK = Tiia Ristolaineni (end Köss) kogu aastatest 1990-2003. 1. osa antud üle Eesti Rahvaluule Arhiivile. 
Tiia Ristolainen

\section{Kirjandus}

Allik, Eha 1969. Eesti surmaennustused. Kursusetöö. Tartu: Tartu Riiklik Ülikool.

Anttonen, Veikko 1992. "Püha" mõiste rahvausundis. Akadeemia 12, lk 2514-2536.

Ariste, Paul 1969. Vadja rahvakalender. Tallinn: Valgus.

Aristoteles 1992. Ennustamisest une abil. Akadeemia 4, lk 698-703.

Arpo, Martin 1996. Noppeid setu vanade matmiskommete kohta. Valk, Heiki \& Västrik, Ergo-Hart (toim). Palve, vanapatt ja pihlakas: Setomaa 1994. a. kogumisretke tulemusi. Vanavaravedaja 4. Tartu, lk 241-267.

Boecler, Johann Wolfgang 1854. Der Ehsten abergläubische Gebräuche, Weisen und Gewohnheiten: Mit auf die Gegenwart bezüglichen Anmerkungen beleuchtet von Dr. Fr. Kreutzwald. St. Petersburg: [s. n].

Danmann, Ernst 1995. Usundiloo alused: Loodususundid, India usundid, budism, Hiina usundid, šintoism, islam, kaasaja uususundid. Tallinn: Logos.

ERKL 1995 = Troska, Gea \& Viires, Ants \& Karu, Ellen \& Vahtre, Lauri \& Tõnurist, Igor. Eesti rahvakultuuri leksikon. Tallinn: Eesti Entsüklopeediakirjastus.

ERE 2000 = Hinrikus, Rutt (koost.). Eesti rahva elulood: Sajandi sada elulugu kahes osas II. Tallinn: Tänapäev.

Eisen, Matthias Johann 1919. Eesti mütoloogia. Tartu: Eestimaa Kooliõpetajate Vastastiku Abiandmise Seltsi raamatukauplus.

Eisen, Matthias Johann 1926. Eesti mütoloogia IV. Eesti Kirjanduse Seltsi toimetused 21. Tartu: Eesti Kirjanduse Selts.

Forselius, Johann \& Boecler, Johann Wolfgang 1914. Der Einfältigen Ehsten Abergläubische Gebräuche, Weisen und Gewohnheiten. Eesti Kirjandus: Lisa. Tartu: Eesti Kirjandus.

Freud, Sigmund 1995. Unien tulkinta. 4. tr. Jyväskylä-Helsinki: Gummerus. Henriku Liivimaa kroonika = Heinrici Chronicon Livoniae 1982. Tallinn: Eesti Raamat.

Hiiemäe, Mall 1996. Nelikümmend lindu eesti rahvausundis I. Mäetagused 1-2, lk 7-23.

Hiiemäe, Mall 1997a. Nelikümmend lindu eesti rahvausundis II. Mäetagused 3, lk 7-18.

Hiiemäe, Mall 1997b. Nelikümmend lindu eesti rahvausundis III. Mäetagused 4, lk 7-19. 


\section{Tiia Ristolainen}

Hiiemäe, Mall 1997c. Nelikümmend lindu rahvausundis IV. Mäetagused 5 , lk 7-22.

Hiiemäe, Mall 1997-1998. Ämblikulaadsed. Putukad. Lülijalgsed. Zooloogia ja Botaanika Instituudi veebilehekülg (http://www.zbi.ee/satikad 11. jaanuar 2004).

Hupel, August Wilhelm 1777. Topographische Nachrichten von Lief- und Ehstland II. Riga: Johann Friedrich Hartknoch.

Jakobson, Kadri 2000. Koerte ohvri tuhk puistatakse merre. SL Õhtuleht, 28. detsember.

Jung, Jaan 1879. Eesti rahwa wanast usust, kombedest ja juttudest. Kodumaalt 6. Tartu: H. Laakmann.

Köss, Tiia 1990. Surmaended Virumaal. Diplomitöö. Käsikiri: Tartu Ülikooli eesi ja võrdleva rahvaluule õppetool.

Köss, Tiia 1994. Marras - dödens framträdande i Virumaa (Virland), Norra Estland. Nord Nytt 56, lk 42-47.

Köss, Tiia 1995. Kiriku ja usuga seotud surmaended. Õpetatud Eesti Seltsi aastaraamat 1988-1993 = Annales Litterarum Societatis Esthonicae. Tartu: Õpetatud Eesti Selts, lk 177-179.

Köss, Tiia 1998. Surmaga seotud uskumused eesti rahvausundis. Magistritöö. Tartu: Tartu Ülikooli eesi ja võrdleva rahvaluule õppetool.

Loorits, Oskar. 1927. Liivi rahva usund: Mit einem Referat: Der Volksglaube der Liven II. Acta et Commentationes Universitatis Tartuensis (Dorpat) B XII: 1 = Tartu Ülikooli toimetused B, Humaniora 12: 1. Tartu: Tartu Ülikool.

Loorits, Oskar. 1932a. Eesti rahvausundi maailmavaade. Elav Teadus 12. Tartu: Eesti Kirjanduse Selts.

Loorits, Oskar 1932b. Der Tod in der livischen Volksüberlieferung. Oppetatud Eesti Seltsi Toimetused = Verhandlungen der Gelehrten Estnischen Gesellschaft 26. Tartu: Õpetatud Eesti Selts, lk 170-200.

Loorits, Oskar 1933. Eesti rahvaluule ja usund. Tartu: Loodus. Äratrükk väljaandest: Kleis, Richard (peatoim). Eesti Entsüklopeedia II, Tartu: Loodus 1932-1933, vrg 797-812.

Loorits, Oskar 1940. Maagilisest mõtteviisist. Rahvapärimuste Selgitaja 1 (8). Tartu: Eesti Rahvaluule Arhiiv, lk 1-10.

Loorits, Oskar 1949. Grundzüge des estnischen Volksglaubens 1. Skrifter Utgivna av Kungl. Gustav Adolfs Akademien för Folklivsforskning 18: 1. Uppsala \& Köpenhamn: Lundequistska Bokhandeln \& Munksgaard.

Loorits, Oskar 1951-1953. Grundzüge des estnischen Volksglaubens 2: 1-2. Skrifter Utgivna av Kungl. Gustav Adolfs Akademien för Folklivsforsk- 


\section{Tiia Ristolainen}

ning 18: 2. Uppsala \& Köpenhamn: Lundequistska Bokhandeln \& Munksgaard.

Loorits, Oskar 1957-1960. Grundzüge des estnischen Volksglaubens 3: 1-2. Skrifter Utgivna av Kungl. Gustav Adolfs Akademien för Folklivsforskning 18: 3. Uppsala \& Köpenhamn: Lundequistska Bokhandeln \& Munksgaard. Masing, Uku 1995. Eesti usund. Tartu: Ilmamaa.

Meyer, Carl 1884. Der Aberglaube des Mittelalters und der nächtsfolgenden Jahrhunderte. Basel: Schneider.

Mikkor, Marika 1996. Linnud, loomad, ebaselge päritoluga hääled ja unenäod surmaennetena Kaukaasia eestlastel. Pärdi, Heiki (peatoim.). Eesti Rahva Muuseumi aastaraamat XLI. Tartu: Eesti Rahva Muuseum, lk 167181.

Mikkor, Marika 2001. Muutuvast matusekombestikust linnas ja maal. Anepaio, Terje (peatoim.). Eesti Rahva Muuseumi aastaraamat XLV. Tartu: Eesti Rahva Muuseum, lk 103-147.

Moor, Argo 1998. Hingepuu: Vanade mü̈̈tide jälgedes. Tartu: Elmatar.

Mäger, Mart 1969. Linnud rahva keeles ja meeles. Tallinn: Eesti Raamat.

Paulson, Ivar 1966. Vana eesti rahvausk: Usundiloolisi esseid. Stockholm: Vaba Eesti.

Pentikäinen, Juha 1987. Suomalaisen kansanperinteen ihmiskuva ja käsitys luonnosta. Helsinki: Helsingin yliopisto.

Qvigstad, Just Knud 1920. Lappischer Aberglaube. Kristiania: Brøgger.

Rahikainen, Päivi 1991. Pohjoista hautausperinnettä. Lapin Maakuntamuseon monisteita 8. Rovaniemi: Lapin Maakuntamuseo, lk 37-44.

Ranke, Karl 1951. Indogermanische Totenverehrung. Folklore Fellows' Communications 140. Helsinki: Suomalainen Tiedeakatemia.

Richter, Elisabet 1976 = Рихтер, Елизавета. Русское население западного Причудья: [Очерки истории, материальной и духовной культуры]. Таллин: Валгус.

Siikala, Anna-Leena 1996. Magia ja kansanusko. Hiidenkivi, lk 10-14.

Simonsuuri, Lauri 1947. Myytillisiä tarinoita. Helsinki: Suomalaisen Kirjallisuuden Seura.

Tedre, Ülo 1985. Elutähtpäevadest ja nendega seotud kommetest. Tedre, Ülo (koost). Vanadest eesti rahvakommetest kaasaegsete tavadeni. Tallinn: Perioodika, lk 36-77.

Tupits, Ave 2002. Tõest ja vaimust ette nähtud lood: Ühe hiidlase usundiline pärimus. Bakalaureusetöö. Tartu: Tartu Ülikool. 


\section{Tiia Ristolainen}

Vahtramäe, Ell 1992. Une nägu peeglis: [Antoloogia Fr. R. Kreutzwaldi nimelise Kirjandusmuuseumi rahvapärimuslike materjalide põhjal]. Tallinn: Valgus.

Valk, Ülo 1998. Inimene ja teispoolsus eesti rahvausundis. Berg, Eiki \& Hiiemäe, Mall \& Jansen, Ea et al. (koost \& toim). Eesti rahvakultuur. Tallinn: Eesti Entsüklopeediakirjastus, lk 485-513.

Varonen, Matti 1892. Vainajainpalvelus muinaisilla suomalaisilla. Suomalaisen Kirjallisuuden Seuran toimituksia 87. Helsinki: Suomalaisen Kirjallisuuden Seura.

Vassiljeva, Kai 1996. Hing, nagu sellest arvati Setumaal suvel 1994. Valk, Heiki \& Västrik, Ergo-Hart (toim). Palve, vanapatt ja pihlakas: Setomaa 1994. a. kogumisretke tulemusi. Vanavaravedaja 4. Tartu, lk 217-229.

Vernaleken, Theodor 1859. Mythen und Bräuche des Volkes in Oesterreich: Als Beitrag zur deutschen Mythologie, Volksdichtung und Sittenkunde. Wien: Braumüller.

Vilkuna, Asko 1959. Die Ausrüstung des Menschen für seinen Lebensweg. Folklore Fellows' Communications 179. Helsinki: Suomalainen Tiedeakatemia.

Vinha-Mustonen, Toini 1981. Kuolemannaakka lentää: Keskisatakuntalaisia kuolemanenteitä muistitiedon ajalta. Tyrvään seudun kotiseutuyhdistys ry:n julkaisuja LVII. Tyrvää: Tyrvään seudun kotiseutuyhdistys.

Virtanen, Leea 1974. Kun kello pysähtyi: Tavallisen suomalaisen yliluonnoliset kokemukset. Porvoo: WSOY.

Virtanen, Leea 1977. Telepaattiset kokemukset. Porvoo: WSOY.

Väisänen, Armas Otto 1924. Syntymä, lapsuus ja kuolema: Setukaisten tapoja ja uskomuksia. Kalevalaseuran vuosikirja 4, Helsinki: Söderström, lk 193-223.

Westermarck, Edvard 1991. Tapojen historia: Kuusi akadeemista esitelmää pitänyt Turussa syksyllä 1911. Suomalaisen Kirjallisuuden Seuran toimituksia 545. Helsinki: Suomalaisen Kirjallisuuden Seura.

Wiedemann, Ferdinand Johann 1876. Aus dem inneren und äusseren Leben der Ehsten. St.-Petersburg: Kaiserliche Akademie der Wissenschaften. 